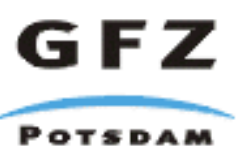

Originally published as:

Mingram, B. (1998): The Erzgebirge, Germany, a subducted part of northern Gondwana: geochemical evidence for repetition of early Palaeozoic metasedimentary sequences in metamorphic thrust units. - Geological Magazine, 135, 785-801.

DOI: $10.1017 / \mathrm{S} 0016756898001769$ 


\title{
The Erzgebirge, Germany, a subducted part of northern Gondwana: geochemical evidence for repetition of early Palaeozoic metasedimentary sequences in metamorphic thrust units
}

\author{
BIRGIT MINGRAM* \\ GeoForschungsZentrum Potsdam, Telegrafenberg B, D-14473 Potsdam, Germany
}

(Received 8 January 1998; accepted 21 August 1998)

\begin{abstract}
One of the major metamorphic terranes of the Bohemian Massif, the Erzgebirge, is interpreted to record a subducted part of a Palaeozoic margin of Gondwana. A geochemical study on noncalcareous metasediments from the various metamorphic units from lower greenschist to granulite facies metamorphism supports a recently established thrust model. Geochemical discrimination and correlation from the metasediments of the Erzgebirge suggest repetition of an early Palaeozoic metasedimentary sequence in metamorphic thrust units. This new finding is in line with recent radiometric dating of intercalated metarhyolitic rocks, which yielded ages of around $480 \mathrm{Ma}$. It is furthermore supported by correlation with a low-grade standard section in Thuringia, which represents the transition from an orogenic belt to a passive margin setting, with highly mature sediments. Significant geochemical signatures have been identified in three different lithotypes, which reappear in at least three metamorphic units of the Erzgebirge. Geochemical correlation of these units was established using simple comparison of averages and with statistical techniques. The identification of significant geochemical signatures from different lithotypes in metamorphic suites has important implications for terrane analysis and reconstruction of ancient tectonic settings.

The repetition of lithologies and their distinct chemical compositions in progressively metamorphosed units is useful for examining element mobility during Barrovian metamorphism. Statistical comparison implies that $\mathrm{Li}$ is progressively depleted from the greenschist to amphibolite facies, whereas $\mathrm{Ca}$ exhibits some enrichment. All the other elements studied are considered to be immobile.
\end{abstract}

\section{Introduction}

The European Variscan Belt is a collision orogen formed during the late Palaeozoic, and is marked by thrusts and nappes (Matte, 1991). Polymetamorphic crystalline nappes with high-pressure, high-temperature relics of eclogites and granulites are widespread from Poland to Spain, and reflect intracontinental and oceanic subduction zones.

The early Palaeozoic history of the Central European Variscides is characterized by crustal extension and development of oceanic basins produced by separation of microplates (e.g. Avalonia, Armorica, and Baltica) from the northern periphery of the Neoproterozoic (Cadomian) supercontinent Gondwana (Matte, 1991; Franke, 1989; Pin, 1990). Bimodal metavolcanic and mafic-ultramafic complexes provide good evidence for extensional rifting regimes in late Cambrian to early Ordovician times (e.g. Pin, 1990; Pin \& Marini, 1993; Winchester et al. 1995; Floyd et al. 1996). The boundary between Proterozoic and the early Palaeozoic times marks an unconformity and/or conformity between crystalline and sedimentary formations of the

\footnotetext{
*E-mail: birgit@gfz-potsdam.de
}

Cadomian basement and highly mature neritic clastic shelf sediments, which pass into hemipelagic shales during the late Ordovician period (Noblet \& Lefort, 1990). These changes reflect the development from an orogenic belt to a passive margin setting with associated widespread shallow marine facies. This development is related to the transition from a Neoproterozoic ensialic arc, the Avalonian-Cadomian orogenic belt, to an early Palaeozoic stable platform at the periphery of a Neoproterozoic supercontinent (Nance \& Murphy, 1994).

Similarities in Palaeozoic depositional settings exist along the major Variscides (Erdtmann, 1991): highmature fine-grained sandstones in the early to middle Arenigian time (Noblet \& Lefort, 1990), chamositic oolitic ore horizons in the Arenigian to Ashgillian times (Young, 1989), and an influence of glaciation in the Upper Ordovician and black shale transgressions in the Arenigian, Llanvirnian and Silurian times. However, the paucity of fossils and the strong tectonometamorphic overprint complicate the correlation of sedimentary sequences and the recognition of ancient geodynamic regimes. In addition to conventional structural and petrological studies, the geochemistry of metamorphic rocks has great potential 
for reconstructing their geological history. Geochemical correlation may be a valid stratigraphical tool if a metamorphic suite of uncertain affinity can be compared with a suite of known stratigraphic position (Winchester \& Max, 1996).

The mineralogical composition of clastic sedimentary rocks is controlled by provenance and tectonic setting, as well as processes of weathering, transport and sedimentation (Schwab, 1975; Dickinson \& Valloni, 1980). Furthermore, chemical and physical transformations during the generation of sediments leads to typical geochemical signatures, which also provide a record of the provenance and sedimentary history (e.g. Sawyer, 1986; Bhatia \& Crook, 1986; Wronkiewicz \& Condie, 1987; Winchester \& Max, 1989; McLennan et al. 1990). The geochemical signatures are responsible for secular trends in the composition of psammitic and pelitic sediments (Cullers, 1995; Cox, Lowe \& Cullers, 1995), and are useful for chemostratigraphic correlation (Hickmann \& Wright, 1983; Schieber, 1990; Winchester \& Max, 1996). During metamorphism, the original composition and framework mineralogy will be changed by metamorphic mineral reactions. Using the geochemical signature of metasediments, it may be possible to reconstruct the original composition if the element variations reflect sedimentary processes and not metamorphism.

However, relatively few studies have been conducted on the geochemical composition of clastic metasediments. Shaw (1954) has shown that most studied elements, with the exception of $\mathrm{Na}, \mathrm{Ca}, \mathrm{Ni}, \mathrm{Cu}, \mathrm{Pb}$ and $\mathrm{Li}$, remain constant during metamorphism. Similar results have been obtained by Rösler \& Beuge (1983) and Haack et al. (1984). Other authors have demonstrated a large-scale fluid flow and significant mass transfer during prograde metamorphism (e.g. Fyfe, Price \& Thompson, 1978; Ferry, 1982), which suggest higher rates of element mobility during devolatilization, metasomatic alteration, and segregation processes. Since Ague (1991), the discussion regarding compositional changes during metamorphism of clastic metasediments has remained controversial (e.g. Ague, 1994; Moss et al. 1995) but has been assisted by mass-balance relations (Ague, 1991, 1994) and statistical analyses (Cardenas et al. 1996). Factors that make it hard to prove metamorphic mobility unequivocally include the difficulty in finding sequences in which a single unit has clearly been subjected to progressive metamorphism, the possibility of spatial protolith differences, overgeneralizations regarding metamorphic grades in previous studies, and the presence of retrograde processes. Accurate field studies, careful sampling procedures, detailed petrographic and petrological examinations, and geochemical studies are required to exclude the influence of recrystallization and cleavage as well as quartz segregation, all of which obscure the original composition. The aim of this paper is therefore: (a) to identify the protolith lithology by evaluating the major and trace element composition of metasedimentary sequences, which are represented by five metamorphic units ranging from lower greenschist through amphibolite to granulite facies;

(b) to examine geochemical signatures from typical metasediments, in order to determine how these correlate with a low-grade reference profile by applying statistical techniques, and to consider the issue of mass transfer;

(c) and to establish a new lithological reconstruction of the Erzgebirge tectonometamorphic pile in accordance with the thrust model.

\section{Geological setting}

\section{2.a. The western Erzgebirge}

The Erzgebirge is situated at the northern border of the Bohemian Massif in the Saxo-Thuringian Zone, and forms one of the major metamorphic crystalline complexes of the European Variscan Belt (Fig. 1). This large NE-SW trending anticline extends over $120 \mathrm{~km}$ in length and $45 \mathrm{~km}$ in width, and plunges slightly to the southwest. The Erzgebirge crystalline complex exposes a seemingly coherent sequence of high- to medium-grade para- and orthogneisses, mica schists containing intercalations of metabasalts, metarhyolites and marbles, and is covered by phyllites. To the northwest, the Erzgebirge crystalline complex is tectonically overlain by very lowgrade early Palaeozoic neritic to hemipelagic sequences.

Opposing views on the evolution of the Erzgebirge have been discussed from as early as the beginning of this century: Kossmat (1927) favoured allochthonous thrusting for the subhorizontal units, and Pietzsch (1962) divided the crystalline complex into parautochthonous gneisses, mica schists and phyllites, and interpreted this succession in a lithostratigraphical sense. According to the most recent theory, Lorenz and Hoth (1990) have described the Erzgebirge as a classic metamorphic terrane with nearly undisturbed Upper Proterozoic to early Palaeozoic rock sequences. A continuous increase in metamorphic grade from greenschist facies to the upper amphibolite facies was suggested for the Erzgebirge crystalline rocks.

In contrast, recent studies on eclogites of the Erzgebirge using conventional geothermobarometry have shown relics of high-pressure and high-temperature metamorphism of $\geq 29 \mathrm{kbar} />800^{\circ} \mathrm{C}$ in the central part and $<24 \mathrm{kbar} /<650^{\circ} \mathrm{C}$ in the western part (Schmädicke, Okrusch \& Schmidt, 1992, Schmädicke \& Evans, 1997). Further petrological studies on metasediments and felsic orthogneisses (Willner, Rötzler \& Maresch, 1997; Rötzler et al. 1998) have led to a recognition of several metamorphic units with separate pressure and temperature histories (Fig. 2; Table 1). The Erzgebirge consists of a stack of discrete metamorphic units that are from the deepest to the highest structural level: 


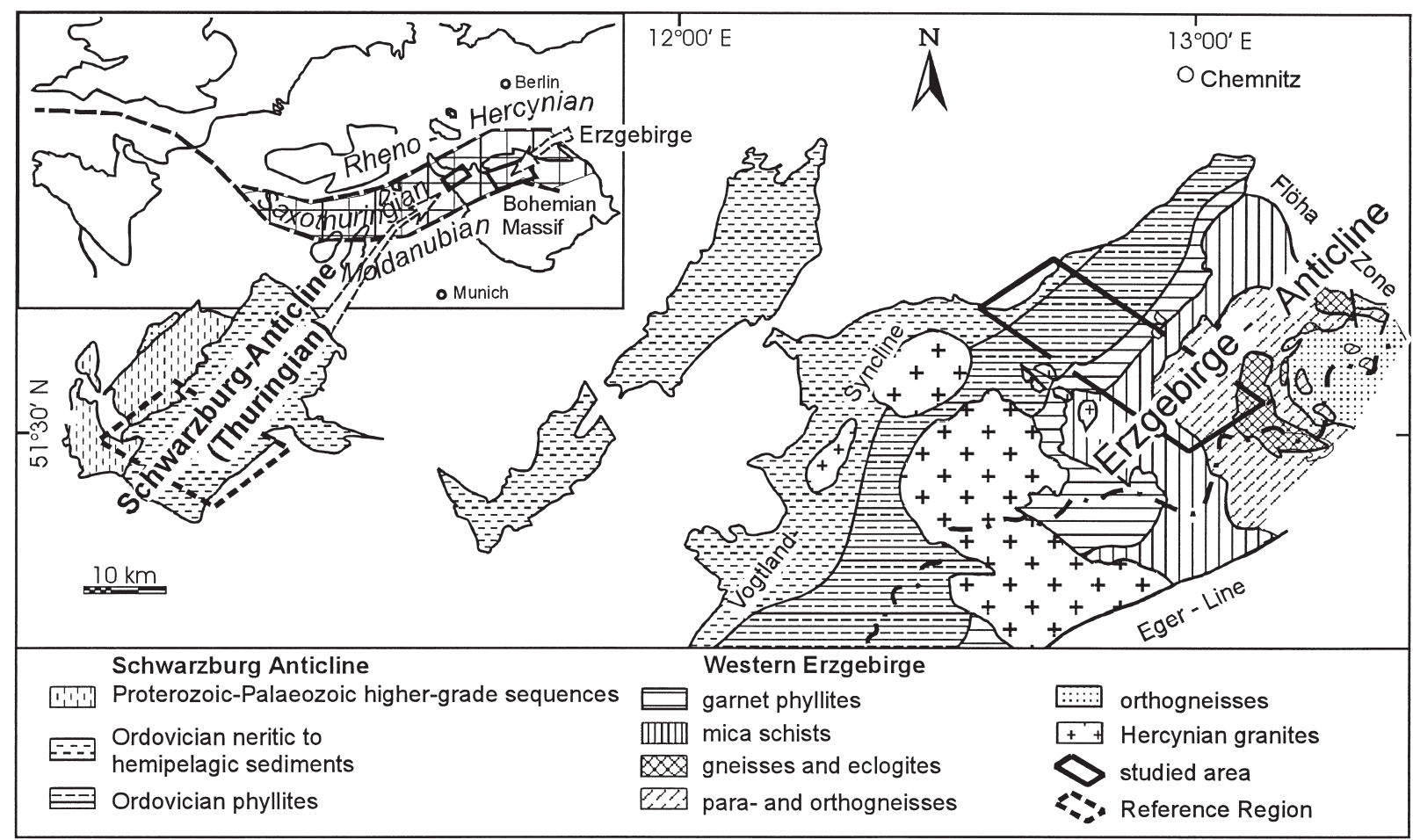

Figure 1. Geological sketch map of the exposed Variscan basement showing the locations of the reference region Thuringia and the Erzgebirge. Note that this map represents only the western part of the Erzgebirge Anticline.

Table 1. Metamorphic units of the Erzgebirge with lithological composition and protolith ages

\begin{tabular}{|c|c|c|c|}
\hline $\begin{array}{l}\text { Metamorphic } \\
\text { units }\end{array}$ & $\begin{array}{l}\text { Pressure and } \\
\text { temperatures }\end{array}$ & Lithological composition & $\begin{array}{l}\text { Protolith } \\
\text { ages }\end{array}$ \\
\hline Phyllite Unit & $\begin{array}{l}\text { low-pressure/ } \\
\text { low-temperature } \\
\sim 2 \mathrm{kbar} / 300^{\circ} \mathrm{C}^{(1)}\end{array}$ & $\begin{array}{l}\text { spilites, limestones, graphite phyllites, chert, } \\
\mathrm{C}_{\text {org }} \text { /graphite-bearing phyllites, quartzites } \\
\text { albite-bearing phyllites, amphibolites }\end{array}$ & $\begin{array}{l}\text { Silurian } \\
\text { graptolites }^{(3)}\end{array}$ \\
\hline Garnet-Phyllite Unit & $\begin{array}{l}\text { medium-pressure/ } \\
\text { low-temperature } \\
\sim 9 \mathrm{kbar} / 470^{\circ} \mathrm{C}^{(1)}\end{array}$ & $\begin{array}{l}\text { amphibolites, limestones, graphite phyllites, } \\
\mathrm{C}_{\text {org }} \text { graphite-bearing phyllites, } \\
\text { garnet- and albite-bearing phyllites, } \\
\text { feldspar-free, chloritoid-bearing phyllites, } \\
\text { quartzites, metatuffites }\end{array}$ & \\
\hline \multirow[t]{2}{*}{ Mica Schist-Eclogite Unit } & $\begin{array}{l}\text { high-pressure/ } \\
\text { low-temperature }\end{array}$ & $\begin{array}{l}\text { graphite mica schists, } \\
\mathrm{C}_{\text {org }} / \text { graphite-bearing mica schists, } \\
\text { abbite-bearing mica schists } \\
\text { feldspar-free, chloritoid-bearing mica }\end{array}$ & \\
\hline & $\begin{array}{l}P_{\min } \sim 12 \mathrm{kbar} / 550^{\circ} \mathrm{C}^{(1)} \\
P_{\max } \sim 24 \mathrm{kbar} / 550^{\circ} \mathrm{C}^{(2)}\end{array}$ & $\begin{array}{l}\text { schists, paragneisses (metaconglomerate, } \\
\text { metagreywacke and shale), marbles, } \\
\text { orthogneisses (metarhyolites) } \\
\text { eclogites (metabasalts) }\end{array}$ & $\sim 480 \mathrm{Ma}^{(4)}$ \\
\hline \multirow[t]{2}{*}{ Gneiss-Eclogite Units 1 and 2} & $\begin{array}{l}\text { high-pressure/ } \\
\text { high-temperature }\end{array}$ & $\begin{array}{l}\text { albite-bearing mica schists } \\
\text { feldspar-free, kyanite-bearing mica schists } \\
\text { migmatitic paragneisses, migmatitic and }\end{array}$ & \\
\hline & $\begin{array}{l}P_{\min } \sim 22 \mathrm{kbar} / 830^{\circ} \mathrm{C}^{(1)} \\
P_{\max } \sim 28 \mathrm{kbar} / 850^{\circ} \mathrm{C}^{(2)}\end{array}$ & $\begin{array}{l}\text { granulitic orthogneisses (metarhyolites) } \\
\text { eclogites (metabasalts) }\end{array}$ & $\sim 480 \mathrm{Ma}^{(4,5)}$ \\
\hline Cadomian Basement & $\begin{array}{l}\text { medium-pressure/ } \\
\text { medium-temperature } \\
6-8 \mathrm{kbar}, 590-650^{\circ} \mathrm{C}^{(1)}\end{array}$ & $\begin{array}{l}\text { orthogneisses (metagranodiorites) } \\
\text { paragneisses (metagreywackes) } \\
\text { intercalated garnet amphibolites }\end{array}$ & $\sim 550 \mathrm{Ma}^{(6)}$ \\
\hline
\end{tabular}

Data from: (1) Rötzler et al. 1998; Willner, Rötzler \& Maresch, 1997; (2) Schmädicke, Okrusch \& Schmidt, 1992; (3) Hösel, Freyer \& Jäger 1978; (4) Mingram et al. 1998; (5) Willner, Kröner \& Teufel, 1996; (6) Tichomirowa et al. 1996; Kröner et al. 1995. 


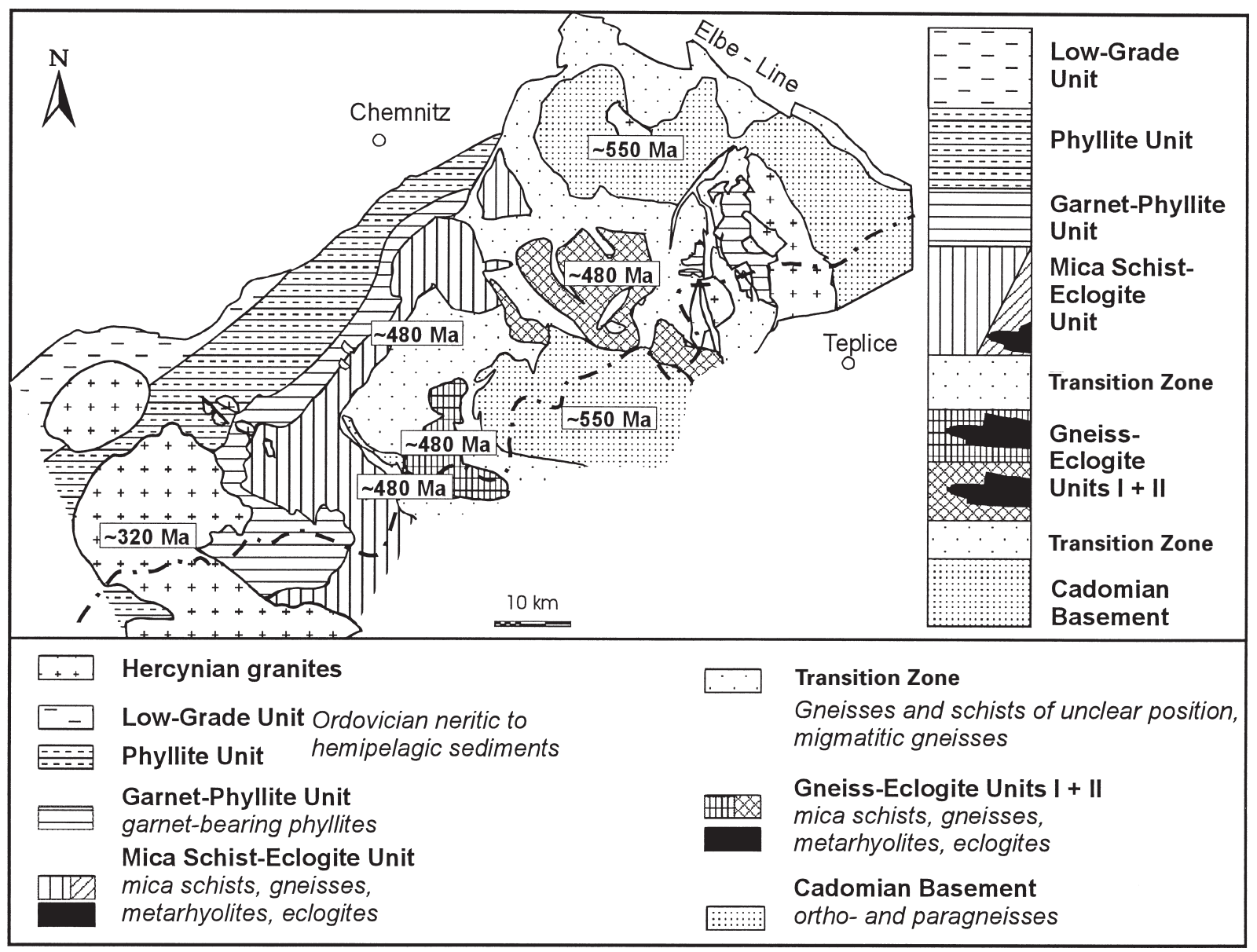

Figure 2. The metamorphic units of the Erzgebirge in a schematic map and in a profile, which represents a stack of the several thrust units. Metamorphic units follow those proposed by Rötzler (1995), Willner, Rötzler \& Maresch (1997), and Rötzler et al. (1998).

(a) a medium-pressure-medium-temperature Gneiss Unit,

(b) two high-pressure-high-temperature GneissEclogite Units,

(c) a high-pressure-low-temperature Mica SchistEclogite Unit,

(d) a medium-pressure-low-temperature GarnetPhyllite Unit,

(e) and a Phyllite Unit.

The lithological composition and radiometric data of these units are shown in Table 1. The lowermost unit consists of para- and orthogneisses with granodioritic composition and intercalated garnet amphibolites. The Gneiss-Eclogite units are sequences of mainly felsic orthogneisses intercalated with eclogites, metagreywackes, marbles and highly mature metapelites. Both these units are separated from the basement and upper part by transition zones with gneisses of uncertain position. Most of the high-grade rocks were recrystallized at amphibolite facies, and preserved only relics of their earlier high-pressure development. Similar lithologies, including felsic orthogneisses, eclogites, marbles, paragneisses, and highly mature metapelites with intercalated quartzites are also found in the succeeding Mica Schist-Eclogite
Unit. Mica schists represent the main rock types of this unit, and can be subdivided into feldspar-free schists, albite-bearing schists, and graphite-bearing schists. These lithological sequences are repeated in the Garnet-Phyllite Unit and in the Phyllite Unit. Biostratigraphical data and the lithological similarity indicate the correlation of the Phyllite Unit with lowgrade early Palaeozoic rocks of the Schwarzburg Anticline.

The ${ }^{207} \mathrm{~Pb} /{ }^{206} \mathrm{~Pb}$ single zircon dating of orthogneisses of the medium-pressure-medium-temperature gneisses yielded protolith ages of around $550 \mathrm{Ma}$ (Tichomirowa et al. 1996; Kröner et al. 1995), while metarhyolites intercalated in high-pressure units have resulted in 480 Ma protolith ages (Willner, Kröner \& Teufel, 1996; Mingram et al. 1998).

The formation of this tectonometamorphic pile is interpreted as a result of continent-continent collision processes during Variscan Orogeny (Rötzler et al. 1998). The high-pressure nappes have been overthrust on a Cadomian basement during and after exhumation processes of a overthickened crust, and underwent amphibolite-facies recrystallization. The Variscan Orogeny culminated in the intrusion of Hercynian granites (330-290 Ma). 


\section{2.b. The Schwarzburg Anticline}

The reference region, the Schwarzburg Anticline, is almost entirely composed of predominantly detrital Neoproterozoic to Silurian neritic to hemipelagic sedimentary rocks. Marked breaks in the mineralogical and geochemical composition were found in the Upper Proterozoic to Silurian sequences (Fig. 3) (Hahne et al. 1984; Maaß et al. 1986). The entire Thuringian Ordovician section is characterized by high maturity, and consequently has a distinctive chemical composition compared to the Upper Proterozoic rocks. The Proterozoic siliciclastics are composed of turbiditic greywackes and mudstones, which contain quartz, white mica, plagioclase, and chlorite, and have high contents of $\mathrm{Na}, \mathrm{Ca}, \mathrm{Sr}$, and $\mathrm{Ba}$. These rocks were intruded by granites of Cadomian age (Gehmlich et al. 1997).

No angular unconformity exists between the Cadomian Basement and the overlying shelf deposits, which are widespread and characterized by mostly clastic, finely laminated or coarse-bedded, pelitic to sandy sequences. The plagioclase content decreases progressively in the Goldisthal group. This trend culminates in extreme depletion of $\mathrm{Ca}, \mathrm{Na}$, and $\mathrm{Sr}$, and an enrichment of $\mathrm{K}$ and $\mathrm{Rb}$ in the Frauenbach group, which is absolutely free of feldspar. The loss of $\mathrm{Ca}$,

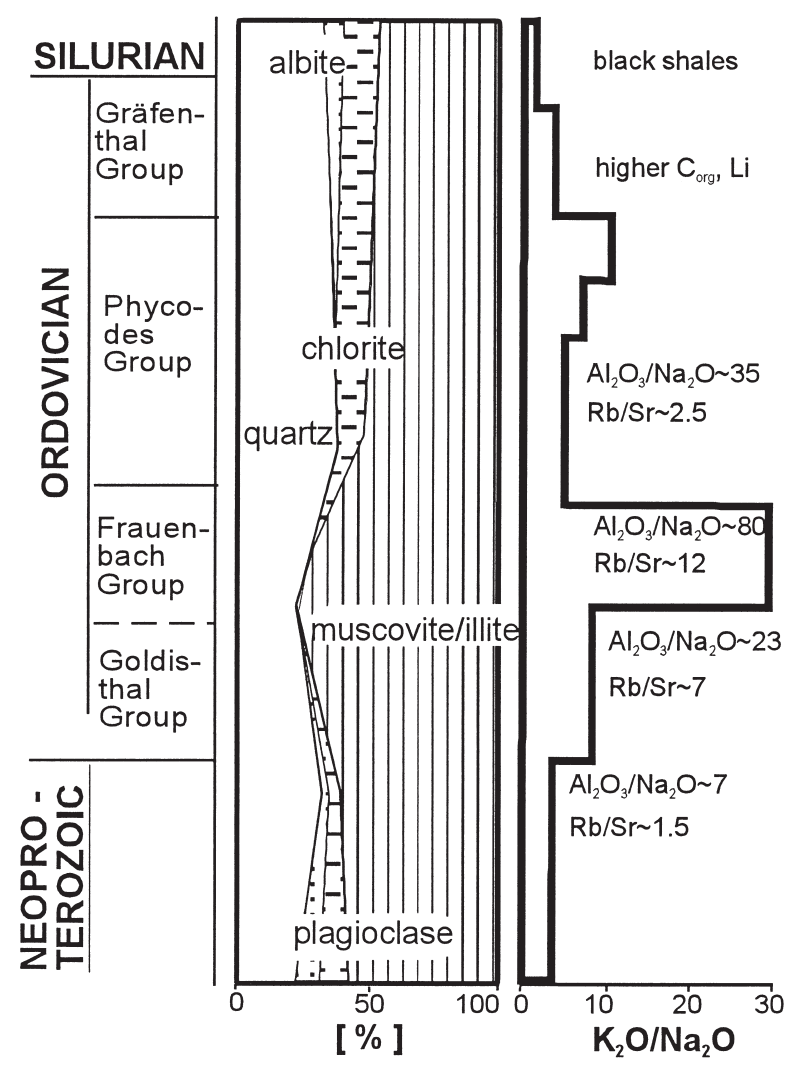

Figure 3. Mineralogical and geochemical characterization of pelitic rocks from the Schwarzburg Anticline after Hahne et al. (1984) and Maaß et al. (1986). Element ratios define secular trends during this time.
$\mathrm{Na}$, and $\mathrm{Sr}$, the high maturity of the quartzitic sandstones, and the abundant heavy mineral content indicate extreme weathering conditions in the source area, and sorting by long transport and recycling. Recent ${ }^{207} \mathrm{~Pb} / 206 \mathrm{~Pb}$ single zircon determinations from intercalated rhyolites yield $489 \pm 5 \mathrm{Ma}$ for the Goldisthal Group, and $477 \pm 5 \mathrm{Ma}$ for the Frauenbach Group, indicating the absence of Cambrian and presumably Tremadocian rocks in the Schwarzburg Anticline sequences (Gehmlich et al. 1997).

The overlying Phycodes Group consists of highly mature shales, with characteristic intercalations of basic tuffites and quartzites with high magnetite concentrations at the base. Contents of albite, chlorite, and rutile as well as $\mathrm{Na}, \mathrm{Sr}, \mathrm{Li}$, and $\mathrm{Ni}$ increase progressively from the base of the Phycodes Group, possibly reflecting the influence of basic magmatism, which was active during the extensional regime. The successive sequences of the Goldisthal, Frauenbach, and Phycodes Groups reach a thickness of around $3200 \mathrm{~m}$ in a short period of time, indicative of a very high subsidence rate (Lützner, Ellenberg \& Falk, 1986). The sedimentation rate slows down from the Middle to Upper Ordovician times. The Arenigian to Ashgillian Gräfenthal Group reaches only $600 \mathrm{~m}$, and is characterized by black laminated shales with chamositic ore horizons and intercalated quartzites.

The whole development has been interpreted to reflect the transition from an orogenic Neoproterozoic basement to an extensional regime with bimodal volcanism and transgressive stable shelf systems. Local basin fillings characterize the Lower and Middle Cambrian periods, and intensive chemical weathering of the uplifted terranes followed in the Upper Cambrian time. Sea-level highstand phases led to rapid denudation rates in Tremadocian-Arenigian times (Linnemann \& Buschmann, 1995; Gehmlich et al. 1997).

\section{Sampling and analytical methods}

The western Erzgebirge consists of several metamorphic units that are presented in Figure 2 and summarised in Table 1. All these units are characterized by markedly different metamorphic histories. However, the main rock types of the uppermost units are mica schist and phyllites, which can be divided independent of their metamorphic grade into feldspar-free schists, albite-bearing schists, and graphite-bearing schists. This subdivision is based only on geochemical discrimination, and has been adopted here for simplification.

Two-hundred-and-fifty representative samples of clastic metasediments (gneisses, feldspar-free schists, albite-bearing schists, and graphite-bearing schists) were selected from quarries, recent outcrops, and from eight drill cores of around $1000 \mathrm{~m}$ in depth, along an NW-SE trending profile in the western Erzgebirge. Surface samples weighing approximately $1 \mathrm{~kg}$ each 
were taken from the freshest rocks available; drill core samples weighed $300-500 \mathrm{~g}$. The sample selection covered the entire lithological spectrum, from aluminosilicate to more quartz-rich pelites up to quartzites or greywackes. From the Phyllite Unit to the Mica SchistEclogite Unit the metamorphic differentiation increases, as manifested by segregations of quartz and occasionally feldspar. Late-stage albite porphyroblasts are considered to represent local-scale redeposition induced by pressure release (Rötzler et al. 1998). Rocks of the high-pressure-high-temperature unit are more homogenous than the low-temperature and pressurerelated rocks. However, a precise knowledge of tectonic and petrological relations is necessary to acquire representative rock samples for these geochemical studies. Only groups with certain comparable $\mathrm{Al}_{2} \mathrm{O}_{3}$ intervals have been used for comparison and correlation.

All samples were ground in an agate mill, sieved to $<230$ mesh and homogenized. Major oxides and the trace elements $\mathrm{Rb}, \mathrm{Sr}, \mathrm{Ba}, \mathrm{Ga}, \mathrm{Zr}, \mathrm{Nb}, \mathrm{Cr}, \mathrm{V}$, and $\mathrm{Zn}$ were analyzed by $\mathrm{X}$-ray fluorescence spectrometry on fused glass and pressed powder discs. Total Fe content is given as $\mathrm{Fe}_{2} \mathrm{O}_{3} \cdot \mathrm{H}_{2} \mathrm{O}$ and $\mathrm{CO}_{2}$ were determined by IR-spectrometry after decomposition of rock powder in a $1000^{\circ} \mathrm{C}$ oxygen stream. $\mathrm{La}, \mathrm{Y}, \mathrm{Ni}, \mathrm{Co}, \mathrm{Sc}, \mathrm{Li}$, and Be were determined by inductively coupled plasma atomic-emission spectrometry (ICP-AES) after dissolution by $\mathrm{HF}-\mathrm{HClO}_{4}$. The analytical precision for all methods was continuously checked with international rock-reference material and laboratory standards. The accuracy and precision of all methods has been proven and documented through participation in different international collaborative studies (e.g. Govindaraju et al. 1994). The database compiled for this paper is available from the author upon request.

\section{Geochemistry of metasediments from the Erzgebirge}

\section{4.a. Discrimination of lithotypes}

The average major- and trace-element compositions of all lithologies studied in each metamorphic unit are listed in Table 2.

The plot of chemical index of weathering (CIW) and $\mathrm{K}_{2} \mathrm{O} / \mathrm{Na}_{2} \mathrm{O}$ ratio (Fig. 4) discriminates the metasedimentary rock types according to the chemical maturity of their protoliths. The CIW from Harnois (1988) reflects the alteration of feldspar to clays with leaching of $\mathrm{Na}$ and $\mathrm{Ca}$, and relative accumulation of Al. Because of the adsorption of $\mathrm{K}^{+}$on clay minerals, $\mathrm{K}_{2} \mathrm{O}$ is treated by the CIW as an immobile component as regards surficial alteration. A comparison of diverse weathering profiles of basaltic and granitic rocks shows CIW values of 32-76 for fresh rocks, and 81-99 for strongly weathered residues (Harnois, 1988). According to Nesbitt \& Young (1982), the chemical index of alteration (CIA) combines $\mathrm{K}_{2} \mathrm{O}$ with the leachable components $\mathrm{Na}_{2} \mathrm{O}$ and $\mathrm{CaO}$, starting with

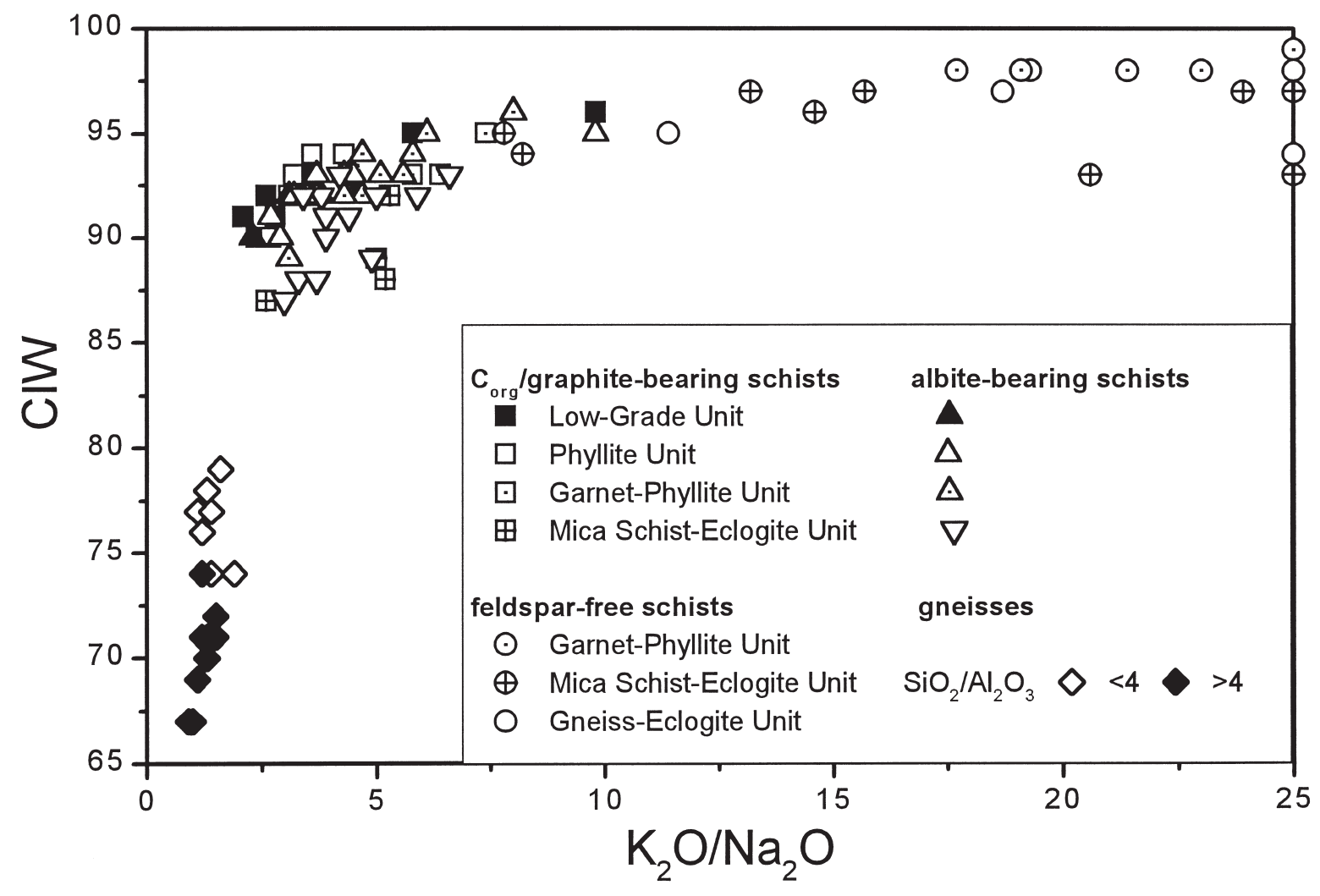

Figure 4. Relation between CIW and the $\mathrm{K}_{2} \mathrm{O} / \mathrm{Na}_{2} \mathrm{O}$ ratio. The main rock types of the western Erzgebirge are divided into $\mathrm{C}_{\text {org }}$ /graphite-bearing schists, albite-bearing schists, feldspar-free schists, and gneisses. $\mathrm{CIW}=\left[\mathrm{Al}_{2} \mathrm{O}_{3} /\left(\mathrm{Al}_{2} \mathrm{O}_{3}+\mathrm{CaO}+\mathrm{Na} 2 \mathrm{O}\right) * 100\right.$ in volatile-free molecular proportions (Harnois, 1988). 
Table 2. Average compositions of clastic metasediments from Erzgebirge metamorphic units and the Thuringia reference region.

\begin{tabular}{|c|c|c|c|c|c|c|c|c|c|c|c|c|c|c|c|}
\hline \multirow[b]{2}{*}{ Unit } & \multicolumn{4}{|c|}{$\begin{array}{l}\text { Gräfenthal Group (Arenig to Ashgill)/ } \\
\text { Corg/graphite-bearing schists }\end{array}$} & \multicolumn{5}{|c|}{ Phycodes Group (Arenig)/ albite-bearing schists } & \multicolumn{4}{|c|}{$\begin{array}{l}\text { Frauenbach Group (Tremadoc-Arenig)/ } \\
\text { feldspar-free schists }\end{array}$} & \multirow{2}{*}{\multicolumn{2}{|c|}{$\begin{array}{c}\text { metagreywackes } \\
\text { gneisses } \\
\text { Mica Schist- } \\
\text { Eclogite } \\
\text { Unit }\end{array}$}} \\
\hline & $\begin{array}{c}\text { Low- } \\
\text { Grade } \\
\text { Unit }\end{array}$ & $\begin{array}{l}\text { Phyllite } \\
\text { Unit }\end{array}$ & $\begin{array}{c}\text { Garnet- } \\
\text { Phyllite } \\
\text { Unit }\end{array}$ & $\begin{array}{l}\text { Mica Schist- } \\
\text { Eclogite } \\
\text { Unit }\end{array}$ & \multicolumn{2}{|c|}{ Low-Grade Unit } & \multirow{2}{*}{$\begin{array}{c}\begin{array}{c}\text { Phyllite } \\
\text { Unit }\end{array} \\
14\end{array}$} & \multirow{2}{*}{$\begin{array}{c}\begin{array}{c}\text { Garnet- } \\
\text { Phyllite } \\
\text { Unit }\end{array} \\
11\end{array}$} & \multirow{2}{*}{$\begin{array}{c}\begin{array}{c}\text { Mica Schist- } \\
\text { Eclogite } \\
\text { Unit }\end{array} \\
14\end{array}$} & \multirow{2}{*}{$\begin{array}{c}\begin{array}{c}\text { Low- } \\
\text { Grade } \\
\text { Unit }\end{array} \\
20\end{array}$} & \multirow{2}{*}{$\begin{array}{c}\begin{array}{c}\text { Garnet- } \\
\text { Phyllite } \\
\text { Unit }\end{array} \\
11\end{array}$} & \multirow{2}{*}{$\begin{array}{c}\begin{array}{c}\text { Mica Schist- } \\
\text { Eclogite } \\
\text { Unit }\end{array} \\
11\end{array}$} & \multirow{2}{*}{$\begin{array}{c}\begin{array}{c}\text { Gneiss- } \\
\text { Eclogite } \\
\text { Unit }\end{array} \\
4\end{array}$} & & \\
\hline $\begin{array}{l}n \\
{[\mathrm{wt} \%]}\end{array}$ & 7 & 6 & 4 & 4 & TB & 9 & & & & & & & & 8 & 12 \\
\hline $\mathrm{SiO}_{2}$ & 50.9 & 55.3 & 54.9 & 62.2 & 60.2 & 58.2 & 59.8 & 57.7 & 61.8 & 54.3 & 52.1 & 62.0 & 64.8 & 63.2 & 67.7 \\
\hline $\begin{array}{l}\mathrm{TiO}_{2}^{-} \\
\mathrm{Al}_{2} \mathrm{O}_{3}\end{array}$ & $\begin{array}{l}1.06 \\
24.5\end{array}$ & $\begin{array}{l}1.04 \\
21.9\end{array}$ & $\begin{array}{l}1.09 \\
23.6\end{array}$ & $\begin{array}{c}0.88 \\
18.4\end{array}$ & $\begin{array}{l}0.93 \\
20.6\end{array}$ & $\begin{array}{l}0.87 \\
21.3\end{array}$ & $\begin{array}{c}0.89 \\
20.4\end{array}$ & $\begin{array}{c}0.99 \\
21.6\end{array}$ & $\begin{array}{c}0.92 \\
19.7\end{array}$ & $\begin{array}{l}1.06 \\
259\end{array}$ & $\begin{array}{l}0.87 \\
236\end{array}$ & $\begin{array}{r}0.81 \\
187\end{array}$ & $\begin{array}{c}0.73 \\
17.6\end{array}$ & $\begin{array}{c}0.78 \\
172\end{array}$ & $\begin{array}{l}0.68 \\
14.8\end{array}$ \\
\hline $\mathrm{Fe}_{2} \mathrm{O}_{3} *$ & $\begin{array}{r}2 . .5 \\
9.3\end{array}$ & 8.70 & 8.04 & $\begin{array}{c}10.4 \\
6.44\end{array}$ & $\begin{array}{c}20.0 \\
6.90\end{array}$ & 7.44 & $\begin{array}{c}20.4 \\
7.16\end{array}$ & $\begin{array}{c}21.0 \\
7.53\end{array}$ & $\begin{array}{r}19.1 \\
6.42\end{array}$ & $\begin{array}{r}25.9 \\
4.61\end{array}$ & $\begin{array}{l}23.6 \\
10.0\end{array}$ & $\begin{array}{c}18.1 \\
7.80\end{array}$ & $\begin{array}{c}17.6 \\
7.60\end{array}$ & $\begin{array}{c}1.2 \\
5.95\end{array}$ & $\begin{array}{c}14.8 \\
4.76\end{array}$ \\
\hline $\mathrm{MnO}^{2}$ & 0.09 & 0.06 & 0.16 & 0.19 & 0.05 & 0.10 & 0.15 & 0.13 & 0.08 & 0.01 & 0.23 & 0.09 & 0.05 & 0.06 & 0.06 \\
\hline $\mathrm{MgO}$ & 2.35 & 2.46 & 2.17 & 2.06 & 1.93 & 1.94 & 1.83 & 1.92 & 1.89 & 1.43 & 1.95 & 1.75 & 1.35 & 2.43 & 1.78 \\
\hline $\mathrm{CaO}$ & 0.31 & 0.15 & 0.32 & 0.61 & 0.31 & 0.25 & 0.14 & 0.24 & 0.34 & 0.09 & 0.08 & 0.31 & 0.31 & 1.20 & 1.45 \\
\hline $\mathrm{Na}_{2} \mathrm{O}$ & 1.14 & 1.10 & 0.88 & 0.98 & 1.32 & 1.32 & 1.11 & 0.95 & 1.10 & 0.22 & 0.17 & 0.34 & 0.18 & 3.07 & 3.09 \\
\hline $\mathrm{K}_{2} \mathrm{O}$ & 3.93 & 3.65 & 5.20 & 4.18 & 3.87 & 4.16 & 4.02 & 4.63 & 4.43 & 8.60 & 5.40 & 4.38 & 4.39 & 3.67 & 3.77 \\
\hline $\mathrm{P}_{2}^{2} \mathrm{O}_{5}$ & 0.14 & 0.11 & 0.09 & 0.17 & 0.10 & 0.08 & 0.09 & 0.09 & 0.11 & 0.06 & 0.08 & 0.10 & 0.16 & 0.17 & 0.16 \\
\hline $\mathrm{H}_{2} \mathrm{O}$ & 5.26 & 5.08 & 3.82 & 3.06 & 3.78 & 4.38 & 4.31 & 4.33 & 3.47 & 3.76 & 5.09 & 3.55 & 2.79 & 2.32 & 1.63 \\
\hline $\mathrm{CO}_{2}$ & 1.68 & 1.70 & 0.33 & 1.15 & 0.14 & 0.22 & 0.16 & 0.15 & 0.25 & 0.44 & 0.22 & 0.22 & 0.26 & 0.50 & 0.27 \\
\hline total & 100.6 & 101.2 & 100.6 & 100.3 & 100.2 & 100.3 & 100.0 & 100.3 & 100.5 & 100.5 & 99.9 & 100.0 & 100.2 & 100.5 & 100.2 \\
\hline $\mathrm{Al}_{2} \mathrm{O}_{3} / \mathrm{Na}_{2} \mathrm{O}$ & 24 & 20 & 27 & 20 & 16 & 18 & 20 & 24 & 19 & 109 & 243 & 201 & 168 & 6.0 & 4.8 \\
\hline $\mathrm{K}_{2} \mathrm{O} / \mathrm{Na}_{2} \mathrm{O}$ & 4.2 & 3.4 & 6.0 & 4.5 & 2.9 & 3.6 & 3.9 & 5.1 & 4.3 & 36 & 54 & 41 & 42 & 1.3 & 1.2 \\
\hline $\mathrm{SiO}_{2} / \mathrm{Al}_{2}^{2} \mathrm{O}_{3}$ & 2.1 & 2.5 & 2.4 & 3.5 & 2.9 & 2.8 & 3.0 & 2.7 & 3.3 & 2.2 & 2.3 & 3.5 & 3.8 & 3.3 & 4.6 \\
\hline $\begin{array}{l}\text { CIW } \\
\text { [ppm] }\end{array}$ & 94 & 95 & 95 & 92 & 93 & 93 & 94 & 95 & 93 & 98 & 99 & 96 & 97 & 80 & 77 \\
\hline $\mathrm{Li}$ & 125 & 121 & 65 & 73 & 111 & 98 & 83 & 89 & 67 & 48 & 36 & 52 & 62 & 78 & 70 \\
\hline $\mathrm{Rb}$ & 232 & 160 & 209 & 169 & 180 & 213 & 202 & 237 & 215 & 427 & 268 & 215 & 253 & 168 & 144 \\
\hline $\mathrm{Sr}$ & 135 & 101 & 107 & 90 & 160 & 112 & 97 & 80 & 90 & 35 & 34 & 41 & 38 & 150 & 153 \\
\hline $\mathrm{Ba}$ & 755 & 692 & 902 & 623 & 780 & 639 & 673 & 754 & 705 & 1285 & 712 & 632 & 446 & 737 & 699 \\
\hline $\mathrm{Be}$ & 4.0 & 3.4 & n.d. & 3.3 & 4.1 & 3.6 & 3.4 & 3.7 & 3.8 & 4.4 & 4.1 & 3.2 & 2.4 & 2.9 & 2.3 \\
\hline $\mathrm{Ga}$ & 31 & 24 & 30 & 25 & 25 & 27 & 25 & 28 & 25 & 31 & 33 & 23 & 18 & 24 & 20 \\
\hline $\mathrm{La}$ & 65 & 56 & 57 & 40 & 61 & 54 & 52 & 52 & 46 & 60 & 50 & 49 & 39 & 39 & 30 \\
\hline Y & 29 & 35 & 39 & 44 & 39 & 27 & 31 & 31 & 30 & 28 & 27 & 35 & 25 & 28 & 25 \\
\hline $\mathrm{Nb}$ & 15 & 16 & 18 & 16 & 17 & 17 & 19 & 22 & 19 & 22 & 16 & 18 & 16 & n.d. & 11 \\
\hline $\mathrm{Zr}$ & 126 & 140 & 185 & 183 & 180 & 151 & 164 & 163 & 211 & 245 & 120 & 201 & 187 & 246 & 256 \\
\hline $\mathrm{Sc}$ & 24 & 21 & 18 & 19 & 16 & 19 & 17 & 17 & 15 & 18 & 17 & 18 & n.d. & 16 & 12 \\
\hline V & 141 & 134 & 131 & 133 & 107 & 113 & 108 & 116 & 108 & 123 & 125 & 97 & 84 & 100 & 66 \\
\hline $\mathrm{Cr}$ & 110 & 111 & 97 & 88 & 82 & 91 & 78 & 99 & 86 & 88 & 99 & 71 & 59 & 87 & 50 \\
\hline Co & 25 & 15 & 16 & 17 & 14 & 19 & 18 & 19 & 17 & 8 & 12 & 16 & 16 & 16 & 12 \\
\hline $\mathrm{Ni}$ & 55 & 36 & 37 & 48 & 40 & 49 & 48 & 51 & 43 & 24 & 31 & 22 & 20 & 41 & 20 \\
\hline $\mathrm{Zn}$ & 117 & 120 & 120 & 122 & 94 & 117 & 112 & 138 & 99 & 52 & 144 & 71 & 55 & 102 & 71 \\
\hline $\mathrm{Rb} / \mathrm{Sr}$ & 1.9 & 1.6 & 2.8 & 2.0 & 1.1 & 2.0 & 2.2 & 3.1 & 2.7 & 12 & 8.1 & 5.7 & 7.8 & 1.2 & 1.0 \\
\hline $\mathrm{Rb} / \mathrm{Li}$ & 2.2 & 1.4 & 3.1 & 2.4 & 1.6 & 2.4 & 2.5 & 2.8 & 3.5 & 9 & 7.2 & 4.3 & 4.3 & 2.2 & 2.2 \\
\hline $\mathrm{Na} / \mathrm{Sr}$ & 66 & 86 & 77 & 76 & 64 & 108 & 89 & 96 & 101 & 50 & 39 & 65 & 43 & 168 & 161 \\
\hline $\mathrm{Ba} / \mathrm{Rb}$ & 3.2 & 4.3 & 4.5 & 3.9 & 4.3 & 3.0 & 3.4 & 3.2 & 3.4 & 2.9 & 2.7 & 3.1 & 1.8 & 4.7 & 5.0 \\
\hline $\mathrm{K} / \mathrm{Rb}$ & 152 & 201 & 225 & 228 & 185 & 172 & 173 & 170 & 179 & 168 & 177 & 178 & 152 & 200 & 227 \\
\hline $\mathrm{Ti} / \mathrm{Zr}$ & 57 & 50 & 37 & 35 & 32 & 36 & 36 & 39 & 36 & 31 & 47 & 28 & 27 & 21 & 17 \\
\hline $\mathrm{La} / \mathrm{Sc}$ & 2.7 & 2.7 & 2.9 & 2.3 & 3.8 & 2.9 & 3.1 & 2.8 & 3.1 & 3.3 & 3.2 & 3.1 & 2.5 & 2.5 & 2.8 \\
\hline
\end{tabular}

Data for the Frauenbach Group Low-grade Unit are from K. Hahne (pers. comm.) 
values of between 50 to 60 for relatively fresh material, and ending with values $>80$ for extreme chemical weathering.

In this study, the CIW clearly discriminates all analysed metasedimentary rock groups, whereas the CIA exhibits homogeneous values. For these reasons, the CIW is preferred. However, the CIW can be misleading for K-feldspar-bearing rocks, as K-metasomatism can change kaolinite into illite, or plagioclase into $\mathrm{K}$-feldspar. In this case, the calculation leads to erroneous values if corrections for $\mathrm{Al}$ in $\mathrm{K}$-feldspar are not made (Fedo, Nesbitt \& Young, 1995). However, all studied metapelites and quartzites are absolutely free of K-feldspar, although K-metasomatic processes during illite genesis cannot be completely ruled out for the metapelites.

The different types of schists show significant differences in chemical composition, which implies considerable changes in geotectonic position, weathering, transport, and sedimentation. The feldspar-free schists exhibit extremely high CIW values of about 95 , and strong depletion of $\mathrm{Na}$ with respect to $\mathrm{K}$ $\left(\mathrm{K}_{2} \mathrm{O} / \mathrm{Na}_{2} \mathrm{O}>10\right)$, which reflects a very mature chemical composition. In some samples, the $\mathrm{Na}_{2} \mathrm{O}$ content tends to zero, and the $\mathrm{K}_{2} \mathrm{O} / \mathrm{Na}_{2} \mathrm{O}$ ratios increase rapidly ad infinitum. For convenience, such samples have been plotted at 25 on the $x$-axis of Figure 4 . The albite-bearing and the $\mathrm{C}_{\text {org }}$ /graphite-bearing schists plot in a field intermediate to the gneisses and feldspar-free schists, having relatively high CIW indices of about $90-95$ and $\mathrm{K}_{2} \mathrm{O} / \mathrm{Na}_{2} \mathrm{O}$ ratios of around 4 . Sedimentary protoliths of these metapelites are significantly more mature than those of the gneisses, but less mature than those of the feldsparfree schists. All albite-bearing and graphite-bearing schists plot in the same field independent of metamorphic overprint.

The protoliths of the gneisses have been interpreted as greywackes due to their lithological variability (i.e. they include metaconglomerates), their relatively high organic carbon contents, and their mineralogical composition. These rocks are characterized by a relatively low CIW of $74-84$, and $\mathrm{K}_{2} \mathrm{O} / \mathrm{Na}_{2} \mathrm{O}$ ratios lower than 2. The lowest CIW is exhibited by gneisses with $\mathrm{SiO}_{2} / \mathrm{Al}_{2} \mathrm{O}_{3}$ ratios higher than 4 ; these may originally have been more psammitic greywackes, with higher portions of feldspar, quartz, and lithic fragments (Wimmenauer, 1984). The gneisses with $\mathrm{SiO}_{2} / \mathrm{Al}_{2} \mathrm{O}_{3}$ ratios lower than 4 reflect a more pelitic origin.

As $\mathrm{SiO}_{2}$ appears to be the most mobile component during metamorphism (Ague, 1994), the influence of grain size should be discussed only using ratios of immobile elements such as $\mathrm{Ti}, \mathrm{Zr}$ and $\mathrm{Al}_{2} \mathrm{O}_{3}$ (Roser \& Nathan, 1997). Figure 5 demonstrates that all studied rock groups show the same trend: the $\mathrm{Zr} / \mathrm{Al}_{2} \mathrm{O}_{3}$ ratios increase with decreasing $\mathrm{Ti} / \mathrm{Zr}$ ratios. With decreasing content of the heavy mineral zircon, represented by zirconium, the phyllosilicate content, represented by

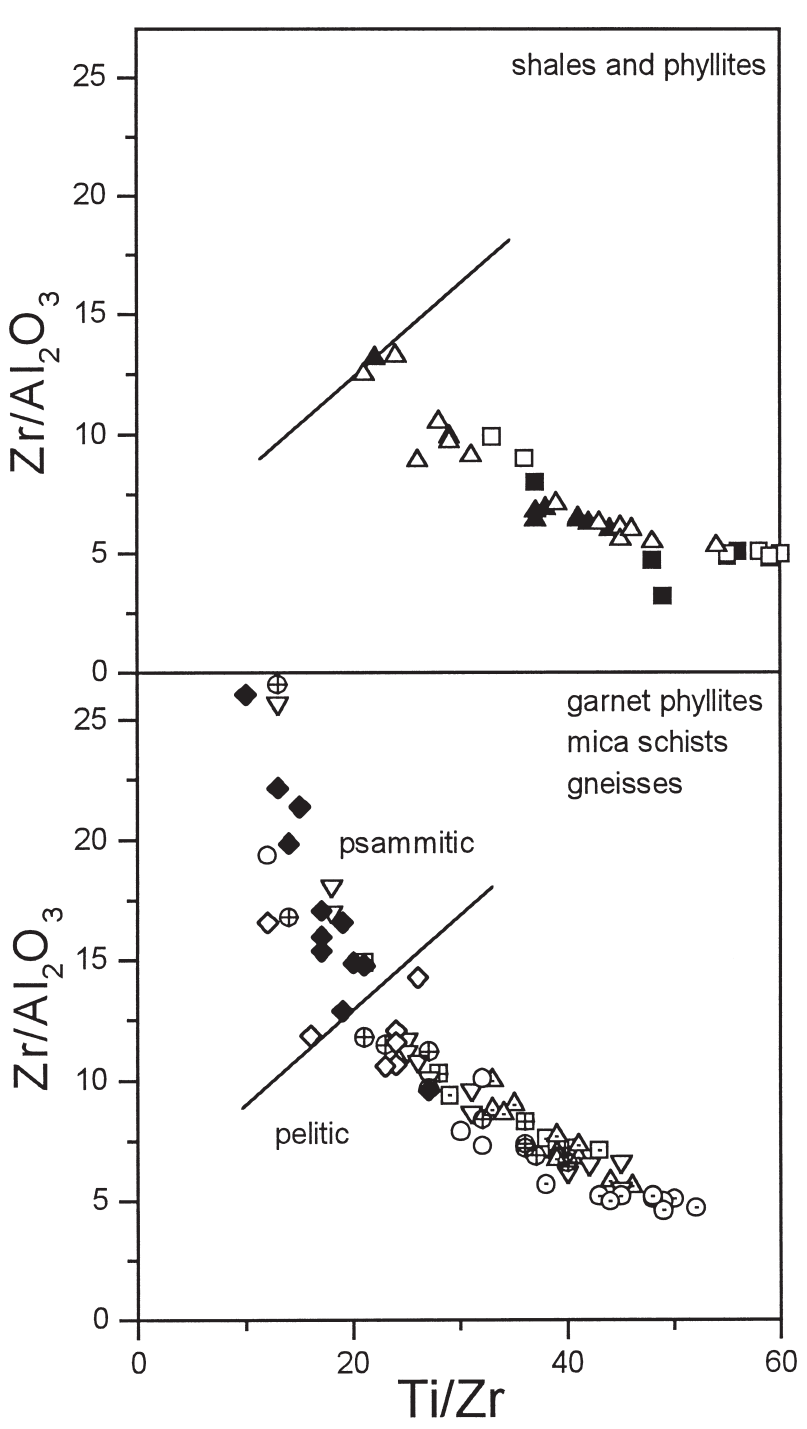

Figure 5. Plot of $\mathrm{Zr} / \mathrm{Al}_{2} \mathrm{O}_{3}$ and $\mathrm{Ti} / \mathrm{Zr}$ for lithotype identification of all studied rock groups. Division in psammitic and pelitic protoliths at $\mathrm{Zr} / \mathrm{Al}_{2} \mathrm{O}_{3}$ ratios according to Roser \& Nathan (1997). Symbols as for Figure 3.

$\mathrm{Al}_{2} \mathrm{O}_{3}$, increases. The quartzites (not presented) also follow this trend.

\section{4.b. Provenance}

The possibility of geochemically discriminating provenance and tectonic setting for sedimentary rocks has been discussed by several authors (e.g. Bhatia \& Crook, 1986; Roser \& Korsch, 1986; Floyd et al. 1991). In general, the amount of volcanic detritus, and consequently $\mathrm{Fe}_{2} \mathrm{O}_{3}, \mathrm{MgO}, \mathrm{TiO}_{2}, \mathrm{Na}_{2} \mathrm{O}, \mathrm{CaO}, \mathrm{V}, \mathrm{Sc}$, and $\mathrm{Cr}$ concentrations decrease progressively from oceanic island arc to passive margin settings. In addition, large ion lithophile (LIL) elements and $\mathrm{SiO}_{2}$ are preferentially enriched in felsic igneous rocks, and are thus indicative of an active continental margin setting.

High $\mathrm{La} / \mathrm{Sc}$ and low $\mathrm{Ti} / \mathrm{Zr}$ ratios in the four rock groups of this study suggest a more felsic source. All 
gneisses exhibit $\mathrm{K}_{2} \mathrm{O} / \mathrm{Na}_{2} \mathrm{O}$ ratios of around 1.3 , and $\mathrm{SiO}_{2}$ contents between 60 to $70 \mathrm{wt} \%$. Such compositions are characteristic of an active continental setting. The schists are characterized by generally high $\mathrm{K}_{2} \mathrm{O} / \mathrm{Na}_{2} \mathrm{O}$ and $\mathrm{Ti} / \mathrm{Zr}$ ratios, and $\mathrm{SiO}_{2}$ content lower than $60 \mathrm{wt} \%$. The associated highly mature quartzites consisting of quartz and resistant heavy minerals (zircon, magnetite, rutile, and tourmaline) are characterized by similar $\mathrm{K}_{2} \mathrm{O} / \mathrm{Na}_{2} \mathrm{O}$ ratios, but have extremely low $\mathrm{Ti} / \mathrm{Zr}$ ratios, and $\mathrm{SiO}_{2}$ contents higher than 80 $\mathrm{wt} \%$. This suggests a history of prolonged and profound weathering, transport, extensive reworking, and sedimentation, which resulted in a nearly complete break down of labile minerals. Such conditions require either old continental recycled sedimentary sources, or periods of tectonic stagnation with sea-level lowstand, which are characteristic of a passive margin setting.

\section{4.c. Compositional comparison of lithotypes}

Spider diagrams (Figs 6a-d) illustrate similarities and differences among the several rock groups in major and trace elements, normalized to average continental Upper Crust (UC) (from Taylor \& McLennan, 1985). In general, the gneisses of the Mica Schist-Eclogite Unit tend to be enriched in $\mathrm{Na}, \mathrm{Ca}, \mathrm{Sr}$, and $\mathrm{Ba}$, illustrated by the ratios of $\left.\mathrm{Al}_{2} \mathrm{O}_{3} / \mathrm{Na}_{2} \mathrm{O} \sim 6\right), \mathrm{K}_{2} \mathrm{O} / \mathrm{Na}_{2} \mathrm{O}$
( 1.3), $\mathrm{Rb} / \mathrm{Sr}(\sim 1.2)$ and $\mathrm{Ba} / \mathrm{Rb}(\sim 5)$. In comparison to all schists, the gneisses are generally richer in $\mathrm{SiO}_{2}$ $(\sim 65 \mathrm{wt} \%)$ and $\mathrm{CaO}(>1.5 \mathrm{wt} \%)$, and poorer in $\mathrm{Fe}_{2} \mathrm{O}_{3}{ }^{*}(<6 \mathrm{wt} \%)$. Except for high $\mathrm{Li}$ and low Sr, Ca, and $\mathrm{Nb}$ content, the gneisses show only small deviations from the UC for most elements (Fig. 6a). Gneisses with $\mathrm{SiO}_{2} / \mathrm{Al}_{2} \mathrm{O}_{3}<4$ are characterized by slightly higher $\mathrm{Li}, \mathrm{Rb}, \mathrm{Al}, \mathrm{Ga}$, and $\mathrm{Y}$ content, and significantly higher $\mathrm{Sc}, \mathrm{Ni}, \mathrm{V}, \mathrm{Cr}$, and $\mathrm{Zn}$ content.

Most of the studied schists exhibit $\mathrm{SiO}_{2}$ content covering a wide range from 48 to $70 \mathrm{wt} \%$. The feldspar-free schists are distinctive from the others in displaying extreme low $\mathrm{Na}, \mathrm{Ca}, \mathrm{Sr}$ and relatively low Li content, significantly higher $\mathrm{Al}_{2} \mathrm{O}_{3} / \mathrm{Na}_{2} \mathrm{O}(\sim 200)$, $\mathrm{K}_{2} \mathrm{O} / \mathrm{Na}_{2} \mathrm{O}(\sim 45), \mathrm{Rb} / \mathrm{Sr}(\sim 8)$ ratios, lower ratios of $\mathrm{Ba} / \mathrm{Rb}(\sim 2.7)$ and low $\mathrm{Nb}, \mathrm{Ni}$, and $\mathrm{Zn}$ levels (Fig. 6b). The elements Rb, K, Al, Ga, La, Ti, Sc, V, and $\mathrm{Cr}$ show up to a twofold enrichment with respect to UC. The loss of $\mathrm{Na}, \mathrm{Ca}, \mathrm{Sr}$, and $\mathrm{Li}$, and the addition of $\mathrm{K}$, $\mathrm{Rb}$, and $\mathrm{Ba}$ are typical for highly weathered and recycled residues. Nesbitt, Markovics \& Price (1980) studied highly weathered profiles and established that large cations ( $\mathrm{Rb}, \mathrm{Cs}, \mathrm{Ba}$, and $\mathrm{K}$ ) can be fixed by ion exchange and adsorption, but smaller cations ( $\mathrm{Li}, \mathrm{Na}$, and Ca) are quite soluble. Sawyer (1986) also found that weathering leads to a release of alkali and alkaline earth elements $(\mathrm{Na}, \mathrm{K}, \mathrm{Rb}, \mathrm{Ca}, \mathrm{Sr}$, and $\mathrm{Ba})$, of

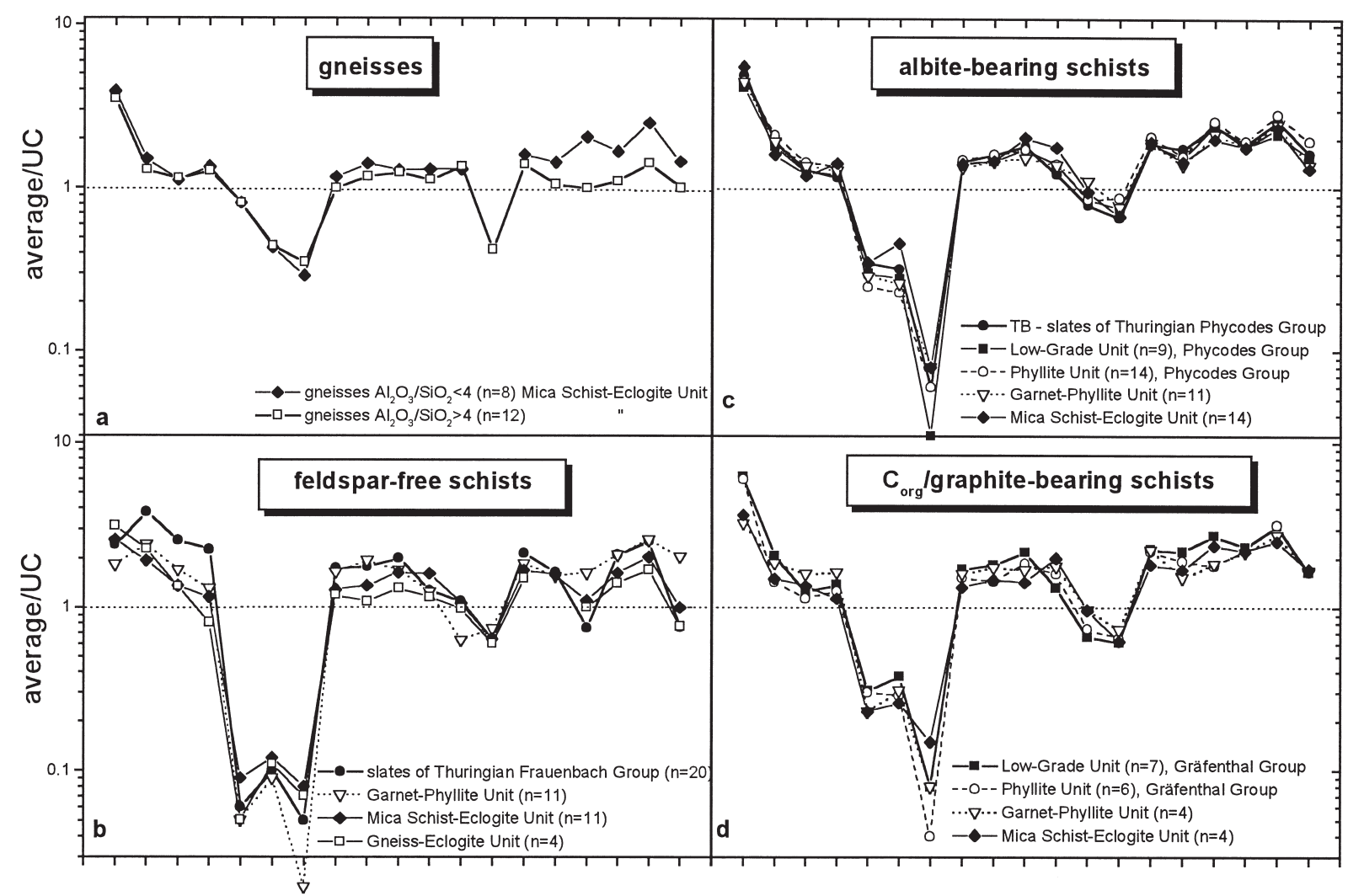

Li Rb K BaNaSr Ca Al GaLa Y Zr Nb Ti Sc Ni V CrZn Li Rb K BaNa SrCaAl GaLa Y Zr Nb Ti Sc Ni V Cr Zn

Figure 6. Major and trace element data for $\mathrm{C}_{\text {org }}$ /graphite-bearing schists, albite-bearing schists, feldspar-free schists, and gneisses of different metamorphosed units. Averages are normalized to Upper Crustal (UC) values according to Taylor \& McLennan (1985). 
which $\mathrm{Ca}, \mathrm{Na}$, and $\mathrm{Sr}$ are soluble whereas $\mathrm{K}, \mathrm{Rb}$, and $\mathrm{Ba}$ are retained by the clay minerals. The feldspar-free schists have a narrow concentration range, and show a small deviation from the schist of the Thuringian Frauenbach Group (Fig. 3).

Metapelitic rocks of the albite-bearing schists from the different greenschist to amphibolite facies units are nearly indistinguishable, having relatively low ratios of $\left.\mathrm{SiO}_{2} / \mathrm{Al}_{2} \mathrm{O}_{3} \sim 3\right)$, high ratios of $\mathrm{Al}_{2} \mathrm{O}_{3} / \mathrm{Na}_{2} \mathrm{O}(\sim 20)$, and intermediate ratios of $\mathrm{K}_{2} \mathrm{O} / \mathrm{Na}_{2} \mathrm{O}(\sim 4), \mathrm{Rb} / \mathrm{Sr}(\sim 2)$ and $\mathrm{Ba} / \mathrm{Rb}(\sim 4)$. They also have high $\mathrm{Fe}_{2} \mathrm{O}_{3}{ }^{*}(8 \mathrm{wt} \%)$ and low $\mathrm{Na}, \mathrm{Ca}$, and $\mathrm{Sr}$ content. The crustal-normalized geochemical signatures of the albite-bearing schists (Fig. 6c) display high Li content, higher enrichment in $\mathrm{Rb}, \mathrm{Al}, \mathrm{Ga}$, and $\mathrm{La}$, and relatively high $\mathrm{Ti}, \mathrm{V}$, $\mathrm{Cr}$, Sc, and $\mathrm{Ni}$ content, but extreme $\mathrm{Ca}$ depletion. $\mathrm{Na}$ and $\mathrm{Sr}$ are depleted, but not as strongly as in the feldspar-free schists. The slates of the Phycodes Group of the Phyllite Unit from the Erzgebirge show comparable compositions to the low-grade Phycodes Group of the Schwarzburg Anticline, and a nearly identical pattern to the higher-grade, albite-bearing schists of the Garnet-Phyllite Unit and the Mica Schist-Eclogite Unit.

The $\mathrm{C}_{\text {org }}$ /graphite-bearing schists (Fig. 6d) are similar to the albite-bearing schists, except for the relatively high organic carbon content (up to $1 \mathrm{wt} \%$ ) and higher $\mathrm{Li}, \mathrm{Mg}, \mathrm{Sc}, \mathrm{Ni}, \mathrm{V}$, and $\mathrm{Cr}$ contents. The geochemical signatures of the metamorphosed schists are comparable with the low-grade equivalents of the Thuringian Gräfenthal Group.

The close association of feldspar-free, albite-bearing and $\mathrm{C}_{\text {org }}$ /graphite-bearing schists in different metamorphic units, and the geochemical similarity of their individual lithologies with different metamorphic grade to the low-grade equivalents of the Schwarzburg Anticline (e.g. Frauenbach Group, Phycodes Group, and Gräfenthal Group) suggest that these Ordovician sediments reappear in different metamorphic units of the Erzgebirge.

\section{Lithological correlations}

This geochemical study provides strong evidence in favour of a model of repetition of early Palaeozoic rocks in higher-pressure metamorphic units. In order to test this model, the lithological profiles and their geochemical characteristic of the high-grade units of the Erzgebirge have been compared to the low-grade reference region of the Schwarzburg Anticline (Fig. 7).

The $\mathrm{C}_{\text {org }}$ /graphite-bearing schists contain slightly sandy layers and occasional pyrite concretions, and have been correlated with the Gräfenthal Group in the reference region. The major rock group in the greenschist facies slates through the Mica Schist-Eclogite Unit is the albite-bearing schist, representing fine pelitic to coarser, sandy grey-green shelf sediments comparable with the Phycodes Group. The feldspar-free schists form a striking lithological group with silty slate protoliths, and associated highly mature quartzites. Because of the complete lack of feldspar, these schists are relatively resistant to weathering, and form morphologically prominent ridges. The occurrence of these unusual feldspar-free rocks in different metamorphic units with typical Al-minerals, such as chloritoid (in the Garnet-Phyllite Unit and the Mica Schist-Eclogite Unit) and kyanite (in the Gneiss-Eclogite Unit), forms the basis of the proposal that the same lithological sequence is repeated in different metamorphic units of the Erzgebirge. Unmetamorphosed equivalents of such rocks occur in the Frauenbach Group of the Schwarzburg Anticline.

The viability of chemostratigraphic correlation of early Palaeozoic rocks from the low-grade Schwarzburg Anticline with metasediments from the higher-grade metamorphic units of the Erzgebirge is supported by:

(a) the transition between paragneisses and schists in the high-pressure units of the Erzgebirge and similar compositional change from greywacke to highly mature sandstones and shales at the Proterozoic-Palaeozoic boundary in the Saxothuringian belt;

(b) the occurrence of extremely mature, feldsparfree schists and their close association with albitebearing and graphite-bearing schists in varying metamorphic units;

(c) the identical chemical composition of the different lithotypes in the variable metamorphic units;

(d) and the early Palaeozoic (about $480 \mathrm{Ma}$ ) protolith ages of intercalated metarhyolites.

\section{Statistical control of lithostratigraphic and geochemical correlation}

The albite-bearing schists have been selected for statistical comparison, as they represent the most data from all metamorphic units. All major element data have been recalculated to $100 \%$ anhydrous, to exclude the effect of depletion or enrichment of volatile phases. Figure 8 demonstrates the correspondence of all albite-bearing schists with the phyllites of the Phycodes Group at an $\mathrm{Al}_{2} \mathrm{O}_{3}$ interval of $20-24 \%$. The compositional comparison after Roser \& Nathan (1997) involves the normalization of averages for each element of the Low-Grade Unit, the Garnet-Phyllite Unit, and the Mica Schist-Eclogite Unit to averages of the equivalent element of the Phyllite Unit Phycodes Group. The \pm 2 standard-deviation interval was calculated to evaluate element variations in the reference group. All schists of various metamorphic grades differ from the reference group in their higher $\mathrm{CaO}$ and lower $\mathrm{MnO}$ contents. Only the TB (schist of the Phycodes Group in the reference region) exhibits an enrichment in Sr. However, no compositional contrast exists for most elements investigated.

Cardenas et al. (1996) have demonstrated the use of 


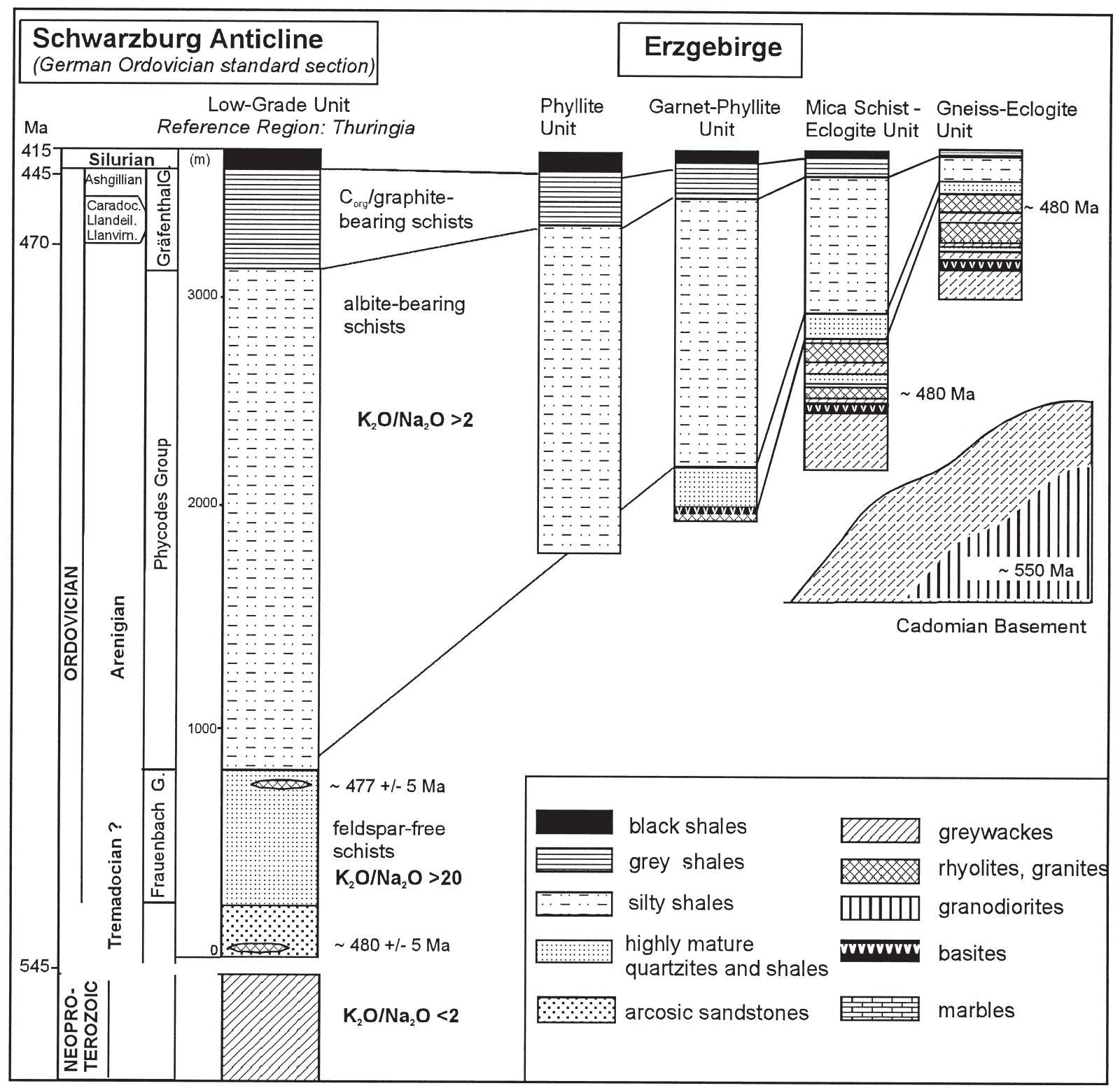

Figure 7. Simplified lithological profiles of the Thuringian standard section (after Lützner, 1986 and Gehmlich et al. 1997) and correlation with the different metamorphic units of the Erzgebirge. All signatures show the protolith lithology.

statistical analysis for the evaluation of lithostratigraphical and geochemical correlations. This method tests for statistically significant differences in average element concentration. To take into account the constant-sum problem, log-ratio transformation is applied. Such transformation overcomes different concentration units and the proportional behaviour of the dataset. All geochemical data were converted to an $\mathrm{Al}_{2} \mathrm{O}_{3}$-normalized, log-transformed dataset, with $\ln \left(\mathrm{SiO}_{2} / \mathrm{Al}_{2} \mathrm{O}_{3}\right), \ln \left(\mathrm{TiO}_{2} / \mathrm{Al}_{2} \mathrm{O}_{3}\right) \ldots, \ln (\mathrm{Rb} / \mathrm{Al}), \ln (\mathrm{Sr} / \mathrm{Al})$. After transformation, data were subjected to analytical procedure including calculation of mean and standard deviation for each metamorphic unit. The next step required application of $\mathrm{F}$-tests to determine equal or non-equal variances between the albite-bearing schist of the Phyllite Unit and the Low-Grade Unit, the Garnet-Phyllite Unit, and the Mica Schist-Eclogite
Unit. A Student T-test was performed to prove the null hypothesis: $\mathrm{H}_{0}: \mu 1-\mu 2=0$, which indicates whether significant differences exist between means for selected elements of two groups. Figure 9 shows the results of the statistical comparison with differences between means and $95 \%$ confidence limit for nine major and 16 trace elements.

$\mathrm{Mn}$ is the only element for which the Phyllite Unit exhibits statistically significant differences in means compared to the other units. Mn is enriched exclusively in the Phyllite Unit. A comparison between the Phyllite Unit and the Garnet-Phyllite Unit shows that $\mathrm{Ca}$ and $\mathrm{K}$ are statistically different, and exhibit enrichment in the higher-grade metamorphic unit. Seven elements ( $\mathrm{Mn}, \mathrm{Ca}, \mathrm{Li}, \mathrm{K}, \mathrm{Rb}, \mathrm{Be}$, and $\mathrm{Cr}$ ) are recognized as statistically significant in the Mica Schist-Eclogite Unit compared to the Phyllite Unit. The mica schists 


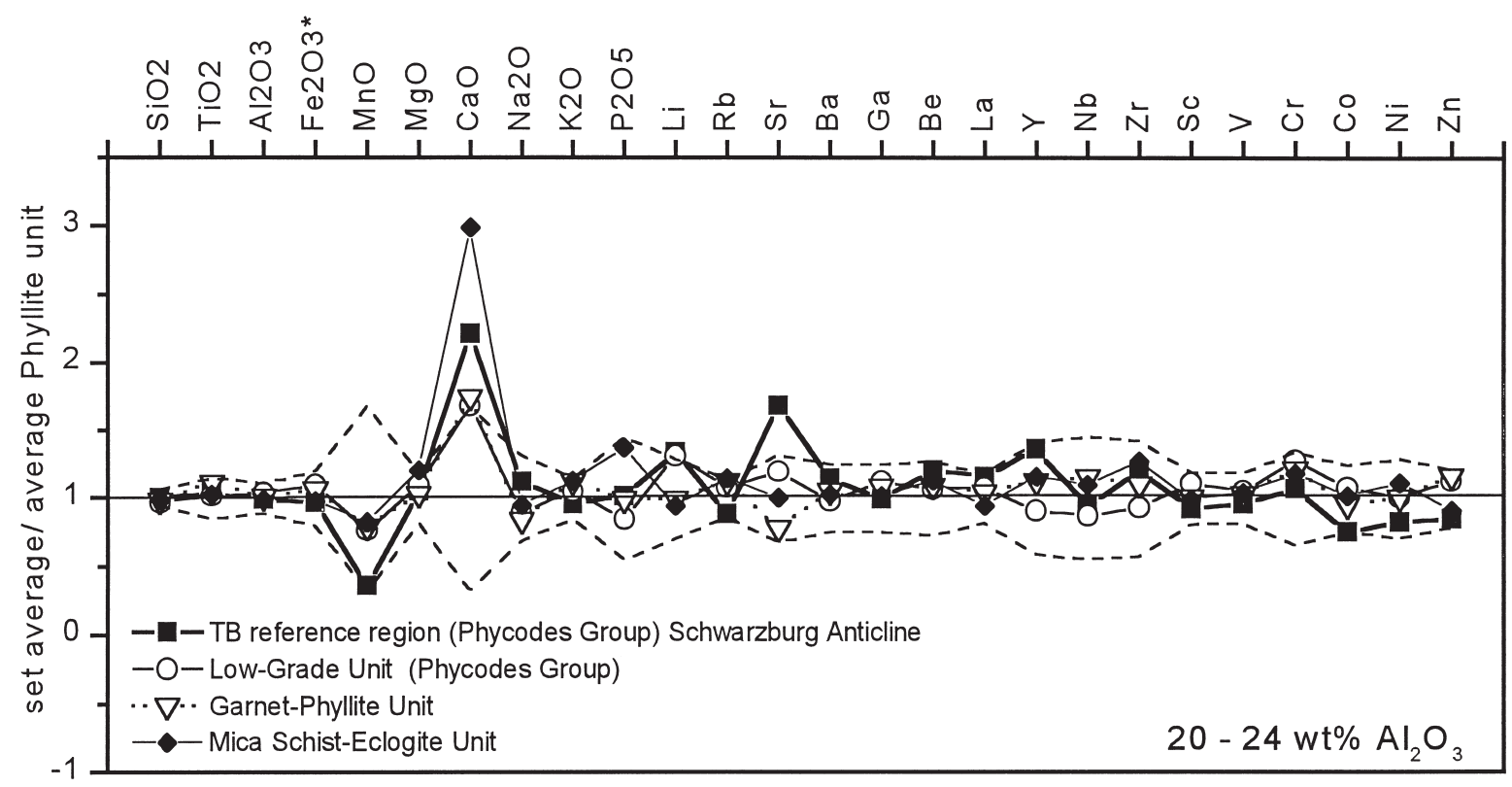

Figure 8. Normalization of the element averages of the Phycodes Group and albite-bearing schists from the reference region Thuringia (TB), the Low-Grade Unit, the Garnet-Phyllite Unit and the Mica Schist-Eclogite Unit with Phyllite Unit average, in the 20-24 wt $\% \mathrm{Al}_{2} \mathrm{O}_{3}$ (anhydrous) interval. Dashed lines are \pm 2 standard deviations about the Phyllite Unit averages. Diagram after Roser \& Nathan (1997).

have lower contents of $\mathrm{Mn}$ and $\mathrm{Li}$, and higher contents of $\mathrm{Ca}, \mathrm{K}, \mathrm{Rb}, \mathrm{Be}$, and $\mathrm{Cr}$. However, $\mathrm{K}, \mathrm{Rb}, \mathrm{Li}$, $\mathrm{Be}$, and $\mathrm{Cr}$ are characterized by differences between means lower than \pm 0.07 (and relatively small standard deviations), resulting in low confidence limits. Consequently, only $\mathrm{Mn}$ and Ca really show depletion and enrichment respectively during progressive metamorphism. However, $96 \%$ of the elements analysed in the Low-Grade Unit, and $92 \%$ of the elements of the Garnet-Phyllite Unit, remain statistically similar to the Phycodes Group schists of the Phyllite Unit. The albite-bearing schists of the Mica Schist-Eclogite Unit exhibit $72 \%$ statistical similarity, compared to the Phycodes Group of the Phyllite Unit, rising to $92 \%$ if the elements with small differences between means are neglected.

\section{Mass loss or gain during metamorphism}

Figure 10 shows enrichment/dilution trends of highgrade facies schists compared to greenschist facies protoliths for four statistically significant elements, according to the residual model of Ague (1994). The residual model (Fig. 10b) is based on the precondition that, if two elements are immobile, data plot in a field passing through the protoliths and the origin towards higher-grade equivalents. Samples plotting in the wedge above this field mark residual enrichment; those plotting below mark residual dilution. Mobile elements may plot outside the wedge, and show loss or gain with respect to immobile species.

Mass calculations for statistically significant elements give low values for $\mathrm{K}_{2} \mathrm{O}(+5.2 \%), \mathrm{Rb}(+6.4 \%)$,
$\mathrm{Be}(+10.5 \%)$ and $\mathrm{Cr}(+12.8 \%)$ in the Mica SchistEclogite Unit when compared to the Phyllite Unit, relative to the reference element Al after Ague (1991, equation 1), whereas $\mathrm{Ca}$ exhibits the highest mass change with an addition to $+143 \%$. Although $\mathrm{Ca}$ is relatively heterogeneous in albite-bearing schists, the $\mathrm{Ca}$ enrichment in the higher-grade metamorphic units could partly reflect the incorporation of $\mathrm{Ca}^{2+}$ in garnet (grossular) and plagioclase with increase in metamorphic grade (Fig. 10a).

The changes in Mn imply a loss of around $-88 \%$. Because the concentration of $\mathrm{Mn}$ in the Phyllite Unit is higher than in the other metamorphic units, the statistical comparison suggests a significant depletion for this element. The field of the Low-Grade Unit and the Phyllite Unit encompasses most samples of the highest metamorphic grade (Fig. 10b). These variations more likely effect the sedimentary protolith variability than metamorphic mobilization or enrichment. $\mathrm{Rb}$ shows a small gain in the higher-grade units (Fig. 10c). Li seems to be slightly depleted $(-19.3 \%)$ in the amphibolite facies mica schists (Fig. 10d). This contrast could be due to the breakdown of Li-bearing minerals (chlorite and biotite) in favour of garnet growth with progressive metamorphism. However, apart from volatile phases such as $\mathrm{H}_{2} \mathrm{O}, \mathrm{CO}_{2}$, and $\mathrm{N}$ (Mingram, Bräuer \& Rötzler, 1996) only Ca and Li clearly exhibit mobilization during metamorphism.

\section{Discussion}

The correspondence of composition and similar geochemical features in the low-grade reference region 
Phycodes Group/albite-bearing schists

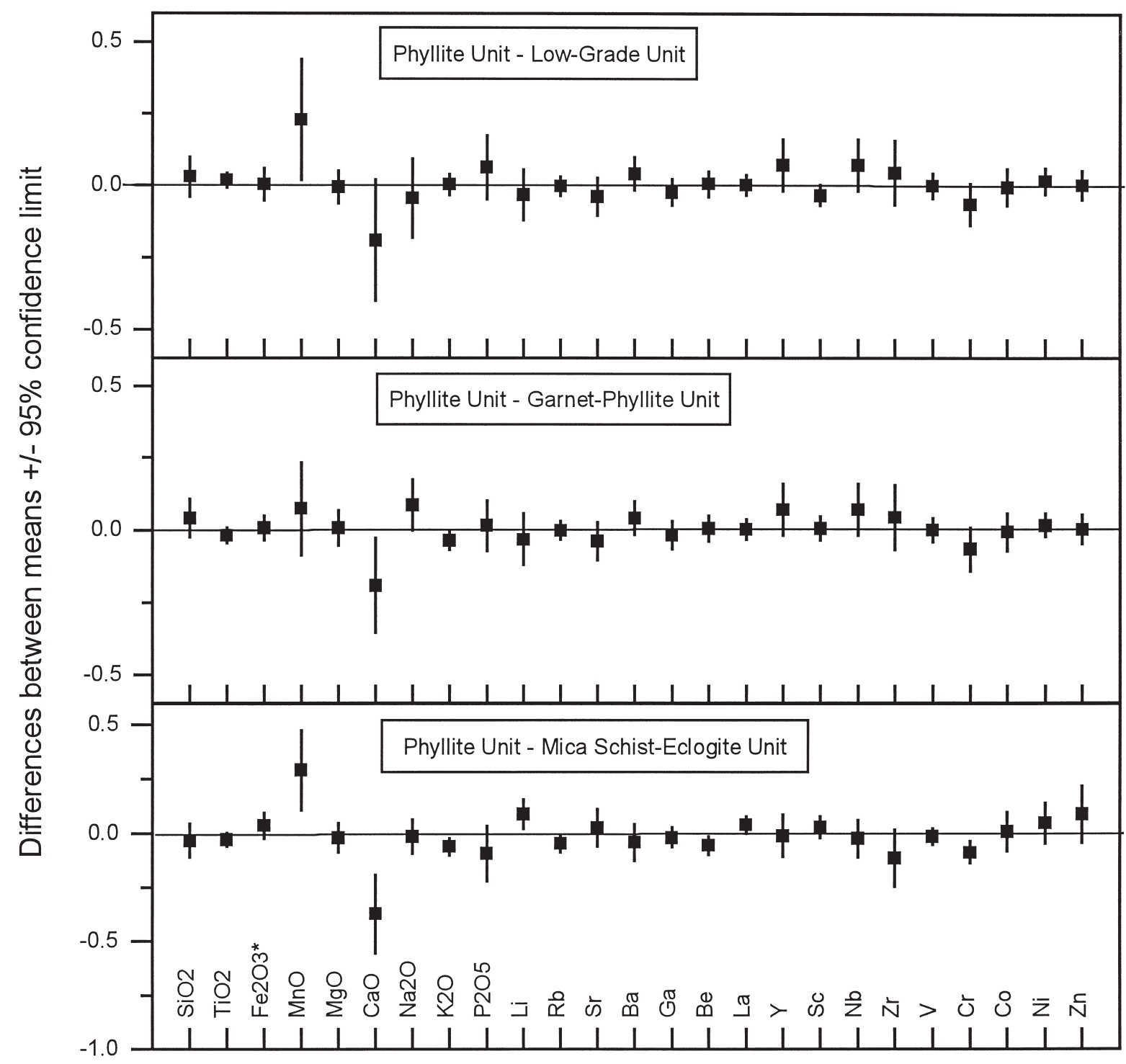

Figure 9. Differences between means of $\ln \left(\right.$ element $\left./ \mathrm{Al}_{2} \mathrm{O}_{3}\right)$ concentrations $(95 \%$ confidence limits of nine major components and 16 trace elements) in the albite-bearing schists from the Phyllite Unit, with albite-bearing schists of the Low-Grade Unit, Garnet-Phyllite Unit, and Mica Schist-Eclogite Unit.

suggests that the weakly-metamorphosed sequence of the Thuringian Ordovician (i.e. feldspar-free Frauenbach Group, albite-bearing Phycodes Group, and the $\mathrm{C}_{\text {org }}$ /graphite-bearing Gräfenthal Group) reappears in the higher-grade metamorphic units of the western Erzgebirge. The combination of eventstratigraphical and geochemical correlation including radiometric dating suggest that the metamorphic units of the Erzgebirge represent a subducted part of the Palaeozoic margin of Gondwana. Recent petrological studies of the Erzgebirge have proposed that the arrangement of lithological successions must take into account the existence of different metamorphic units.

The strong depletion in $\mathrm{Na}, \mathrm{Sr}, \mathrm{Ca}$, and $\mathrm{Li}$, and enrichment in $\mathrm{Rb}, \mathrm{K}, \mathrm{Cs}$, and $\mathrm{Ba}$ in the feldspar-free schists with respect to the Upper Crust indicates a high degree of maturity for the original sediments, which are characteristic of a passive margin setting with intensive weathering and a long history of recycling. The repetition of these geochemically distinctive rocks in several lithostratigraphic units (according to Lorenz $\&$ Hoth, 1990) implies that the same conditions existed in the source region and depositional environment several times during deposition of the sequences. For a normal transgressive sequence such duplication seems to be improbable, particularly since the studied sequences cover a period from Upper Proterozoic to the Ordovician ages. The apparent correlation of these schists with the Frauenbach Group of the Schwarzburg Anticline is given by the same extreme composition of very highly mature, fine quartzitic sandstones and shales. This lithology occurs together with the albite-bearing schists, which are chemostratigraphically comparable with the Phycodes Group. 


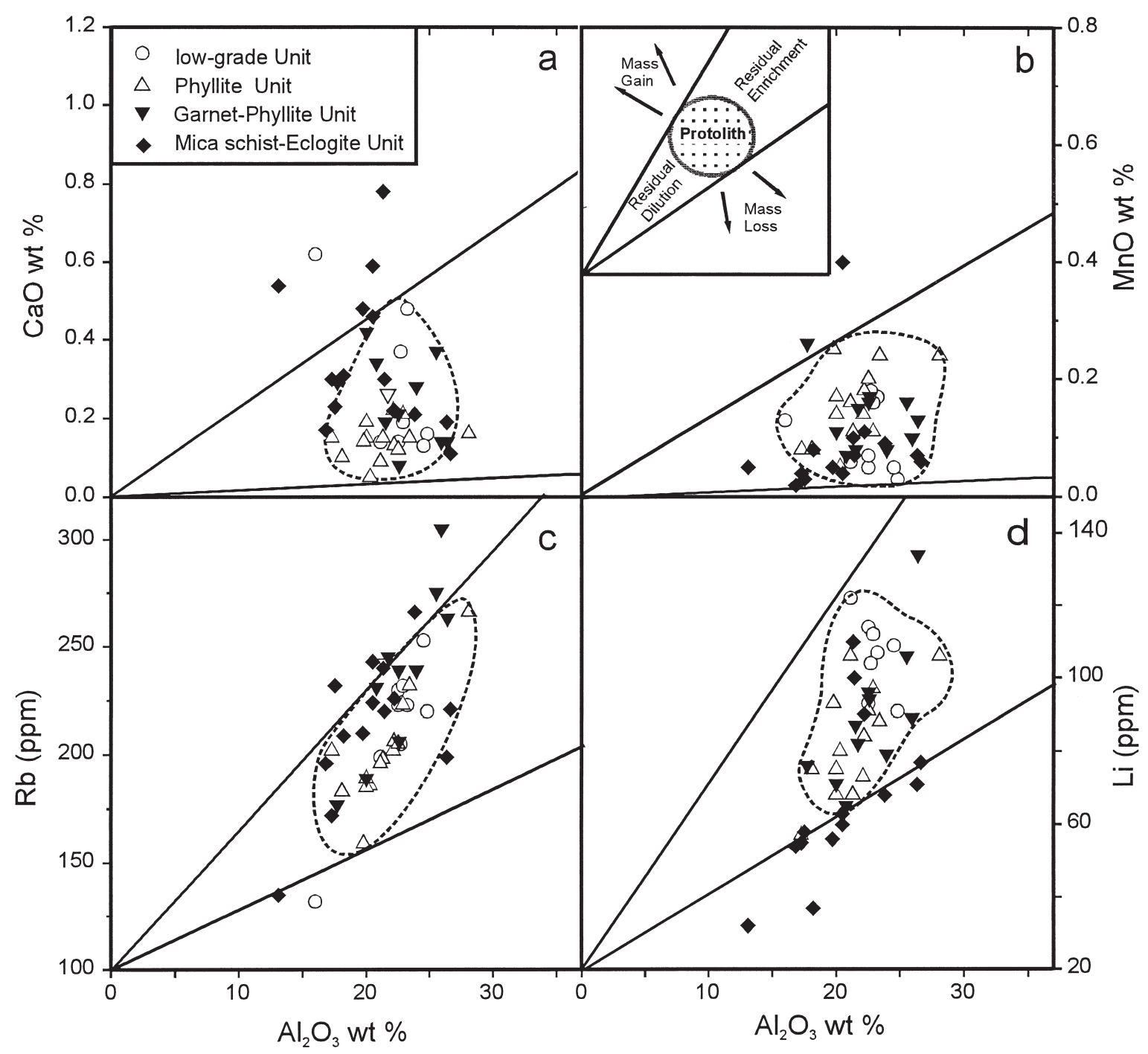

Figure 10. Behaviour during progressive metamorphism of statistically significant elements in the albite-bearing schists relative to $\mathrm{Al}_{2} \mathrm{O}_{3}$. The residual enrichment/depletion model after Ague (1994) is shown in Fig. 10b. The fields outlined by dashed lines are based on samples from the Low-Grade Unit and Phyllite Unit of the Phycodes Group, and characterize lower-greenschist facies protoliths.

Both lithotypes are characterized by high sedimentation rates that mark an episode of strong subsidence. Together with the preceding bimodal volcanism, this period indicates an extensional rift regime. The overlying $\mathrm{C}_{\text {org }}$ /graphite-bearing schists represent hemipelagic conditions.

A sea-level lowstand and/or uplift of the postCadomian shelf in the Upper Cambrian has been postulated for Saxothuringian (Linnemann \& Buschmann, 1995). During this period, intensive chemical weathering of the uplifted basement took place. The feldspar-free schists represent the Lower Ordovician transgressive recycled weathering crust. The overlying Phycodes Group exhibits less reworking, but nevertheless has high maturity. On a regional scale, these sequences correspond to the Arenig Grès Armoricain Formation of the north Gondwana domain, a succession of continental or marine, very mature, fine quartzitic sandstones sometimes associ- ated with conglomerate and arkosic sandstone. The Grès Armoricain Formation and its equivalents is documented over large areas of northern Gondwana margin, where it conformably or unconformably overlies the Cadomian basement (Noblet and Lefort, 1990). This Formation is of special palaeoenvironmental and stratigraphic application (Erdtmann, 1991). The neritic development of the probable Cambrian and early Ordovician sediments changes to hemipelagic sedimentation up to the Middle Ordovician period. The Griffelschiefer of the Gräfenthal Group marks the black-shale transgression from the middle Arenig time. During the late Palaeozoic continent-continent collision these peri-Gondwana passive margin sediments were included in a high pressure regime. The Variscan overthrusting of these units above the Cadomian basement resulted in amphibolite-facies recrystallization of this pile. 


\section{Conclusions}

(a) Lithologically, the clastic metasediments of the Erzgebirge may be clearly separated into four major rock groups irrespective of metamorphic grade: metagreywackes, feldspar-free schist, albite-bearing schists, and $\mathrm{C}_{\text {org }}$ /graphite-bearing schists. Geochemically, these groups can be clearly discriminated, allowing correlation between lithotypes at differing metamorphic grades. All schist types with intercalated quartzites have been identified as passive margin sediments.

(b) Mineralogical and geochemical features of these schists correspond well with a low-grade, Upper Proterozoic to Ordovician sedimentary succession in the reference region Schwarzburg Anticline. The geochemical data provide strong evidence for repetition of the same lithological sequence in different metamorphic units. The comparability of different metamorphosed lithologies has been established using graphical normalization to a low-grade protolith from the Phycodes Group, average compositions from albite-bearing schist, and applying statistical techniques.

(c) These results are consistent with recent radiometric dating of metarhyolites from the high-pressure units, which yield protolith ages of around $480 \mathrm{Ma}$.

(d) Examination of the residual model according to Ague (1994) suggests that, at least in the albite-bearing schists, element mobility did not occur, with the exception of volatile phases $\mathrm{Ca}$ and probably $\mathrm{Li}$.

(e) The Erzgebirge is a high-pressure terrain consisting of stacks from several Palaeozoic thrust units. The combination of event-stratigraphical and geochemical correlation, including radiometric dating, indicate that these units formed a subducted part of a rifted passive margin of Gondwana.

Variations in certain trace and major elements in metasedimentary rocks that are controlled by provenance and geotectonic regimes are a valuable tool in the discrimination and correlation of clastic metasedimentary sequences. In addition, chemostratigraphic correlation with low-grade sedimentary regions permits assignment of stratigraphic ages for identification and reconstruction of ancient high-grade metasedimentary terranes in combination with event-stratigraphic correlation and radiometric dating.

Acknowledgements. This work presents the results of the author's Ph.D. thesis supervised by R. Emmermann and initiated by K. Hahne. I am grateful to E. Kramer, R. Naumann and P. Vogler for doing most of the chemical analyses. Many thanks to K. Rötzler and H. G. Plessen for their helpful comments on various versions of this manuscript. An earlier version of this paper was significantly improved by reviews from E. W. Sawyer and R. L. Cullers. J. Lindsay and B. Trumbull are thanked for correction of the English. The author thanks anonymous reviewers for their helpful suggestions and comments on this manuscript, and J. Holland for the editorial handling.

\section{References}

Ague, J. J. 1991. Evidence for major mass transfer and volume strain during regional metamorphism of pelites. Geology 19, 855-58.

Ague, J. J. 1994. Mass transfer during Barrovian metamorphism of pelites, south-central Connecticut. 1: Evidence for changes in composition and volume. American Journal of Science 294, 989-1057.

Bhatia, M. R. \& CROоK, K. W. 1986. Trace element characteristics of graywackes and tectonic setting discrimination of sedimentary basins. Contributions to Mineralogy and Petrology 92, 181-93.

Cardenas, A. A., Girty, G. H., Hanson, A. D., Lahren, M. M., KNAACK, C. \& JOHNSON, D. 1996. Assessing differences in composition between low-metamorphic grade mudstones and high-grade schists using log-ratio techniques. Journal of Geology 104, 279-93.

Cox, R., Lowe, D. R. \& Cullers, R. L. 1995. The influence of sediment recycling and basement composition on evolution of mudrock chemistry in the southwestern United States. Geochimica et Cosmochimica Acta 59, 2919-40.

Cullers, R. L. 1995. The controls on the major- and traceelement evolution of shales, siltstones and sandstones of Ordovician to Tertiary age in the Wet Mountains region, Colorado, USA. Chemical Geology 123, 107-31.

DiCKInSON, W. R. \& VALlONI, R. 1980. Plate settings and provenance of sands in modern ocean basins. Geology 8, 82-86.

ERdTMAnN, B. D. 1991. The post-Cadomian early Palaeozoic tectonostratigraphy of Germany. Annales de la Societé Géologique de Belgique 114, 19-43.

Fedo, M., Nesbitt, H. W. \& Young, G. M. 1995. Unravelling the effects of potassium metasomatism in sedimentary rocks and paleosols, with implications for paleoweathering conditions and provenance. Geology 23, 921-24.

FERRY, J. M. 1982. A comparative geochemical study of pelitic schists and metamorphosed carbonate rocks from south-central Maine, USA. Contributions to Mineralogy and Petrology 80, 59-72.

Floyd, P. A., Shail, R., Leveridge, B. E. \& Franke, W. 1991. Geochemistry and provenance of Rhenohercynian synorogenic sandstones: Implications for tectonic environment discrimination. Geological Society Special Publication 57, 173-88.

Floyd, P. A., Winchester, J. A., Ciesielczuk, J., Lewandowska, A., Szczepanski, J. \& Turniak, K. 1996. Geochemistry of early Palaeozoic amphibolites from the Orlica-Snieznik dome, Bohemian massif: Petrogenesis and palaeotectonic aspects. Geologische Rundschau 85, 225-38.

FRANKE, W. 1989. Tectonostratigraphic units in the Variscan belt of Central Europe. Special Paper of the Geological Society of America 230, 67-90.

Fyfe, W. S., Price, N. J. \& Thompson, A. B. 1978. Fluids in the Earth's Crust. Amsterdam: Elsevier, 385 pp.

Gehmlich, M., Linnemann, U., Tichomirowa, M., LÜTZNER, H. \& BOMBACH, K. 1997. Datierung und Korrelation neoproterozisch-frühpaläozoischer Profile des Schwarzburger Antiklinoriums und der Elbezone auf der Basis der Geochronologie von Einzelzirkonen. Zeitschrift für Geologische Wissenschaften 25, 191-201.

Govindaraju, K., Potts, P. J., Webb, P. C. \& Watson, J. S. 1994. Report on Whin Sill dolerite WS-E from England 
and Pitscurrie microgabbro PM-S from Scotland. Geostandards Newsletter 18, 211-300.

HaAck, U., Heinrichs, H., Boness, M. \& Schneider, A 1984. Loss of metals from pelites during regional metamorphism. Contributions to Mineralogy and Petrology $\mathbf{8 5}, 116-32$.

Hahne, K., MaAß, I., LÜtzner, H., Ellenberg, J., Falk, F. \& GRUMBT, E. 1984. C-Isotopenuntersuchungen zur Entwicklung des Altpaläozoikums im Thüringischen Schiefergebirge. ZFI-Mitteilungen 85, 107-18.

HARNOIS, L. 1988. The CIW index: A new chemical index of weathering. Sedimentary Geology 55, 319-22.

Hickmann, A. H. \& Wright, A. E. 1983. Geochemistry and chemostratigraphical correlation of slates, marbles and quartzites of the Appin Group, Argyll, Scotland. Earth Sciences 73, 251-78.

Hösel, G., Freyer, G. \& JÄGER, H. 1978. Zum Nachweis von Oberem Graptolithenschiefer in der Erzgebirgsnordrandzone. Zeitschrift für Geologische Wissenschaften 6, 995-1003.

Kossmat, F. 1927. Gliederung des varistischen Gebirgsbaues. Abhandlungen des Sächsischen Geologischen Landesamtes, $1-39$.

Kröner, A., Willner, A. P., Hegner, E., Frischbutter, A., Hofmann, J. \& Bergner, R. 1995. Latest Precambrian (Cadomian) zircon ages and $\mathrm{Nd}$ isotopic systematics for granitoid orthogneisses of the Erzgebirge, Saxony and Czech. Republic. Geologische Rundschau 84, 437-56.

Linnemann, U. \& BuschmanN, B. 1995. Die cadomische Diskordanz im Saxothuringikum (oberkambrischtremadocische overlap-Sequenzen). Zeitschrift für Geologische Wissenschaften 23, 707-27.

Lorenz, W. \& Нотн, K. 1990. Lithostratigraphie im Erzgebirge-Konzeption, Entwicklung, Probleme und Perspektiven. Abhandlungen des Sächsischen Museums für Mineralogie und Geologie 37, 7-35.

LÜTZner, H., EllenberG, J. \& FAlK, F. 1986. Entwicklung der Sedimentationsrate und der Ablagerungsprozesse im Altpaläozoikum Thüringens. Zeitschrift für Geologische Wissenschaften 14, 83-93.

MaAB, I., Hahne, K., Loos, G. \& Vogler, P. 1986. Isotopen- und elementgeochemische Untersuchungen an schwachmetamorphen Sedimenten als Hilfsmittel zur faziellen und stratigraphischen Einordnung. Isotopenpraxis 22, 131-35.

Matte, Ph. 1991. Accretionary history and crustal evolution of the Variscan belt in Western Europe. Tectonophysics 196, 309-37.

Mclennan, S. M., Taylor, S. R., McCulloch, M. T. \& MAYNARD, J. B. 1990. Geochemical and Nd-Sr isotopic composition of deep-sea turbidites: Crustal evolution and plate tectonic associations. Geochimica et Cosmochimica Acta 54, 2015-50.

Mingram, B., BRÄUeR, K \& RötZler, K. 1996. Nitrogenisotope compositions of metasedimentary rocks of different tectonometamorphic units. Journal of Conference Abstracts 1, 405.

Mingram, B., Rötzler, K., Tichomirowa, M., HaAse, G., TeufEL, S. 1998. Early Palaeozoic rift-related magmatism and passive margin sediments preserved in HP units of the Erzgebirge. Terra Nostra 98/2, 105-7.

Moss, B. E., Haskin, L. A., Dymek, R. F. \& Shaw, D. M. 1995. Redetermination and reevaluation of compositional variations in metamorphosed sediments of the Littleton Formation. American Journal of Science 295, 988-1019.
Nance, R. D. \& Murphy, J. B. 1994. Contrasting basement isotopic signatures and the palinspastic restoration of peripheral orogens: Example from the Neoproterozoic Avalonian-Cadomian belt. Geology 22, 617-20.

Nesbitt, H. W. \& Young, G. M. 1982. Early Proterozoic climates and plate motions inferred from major element chemistry of lutites. Nature 299, 715-17.

Nesbitt, H. W., Markovics, G. \& Price, R. C. 1980. Chemical processes affecting alkalis and alkaline earths during continental weathering. Geochimica et Cosmochimica Acta 44, 1659-66.

Noblet, C. \& Lefort, J. P. 1990. Sedimentological evidence for a limited separation between Armorica and Gondwana during the Early Ordovician. Geology 18, 303-06.

Pietzsch, K. 1962. Die Geologie von Sachsen. Berlin: Deutscher Verlag für Wissenschaften, $870 \mathrm{pp}$.

PiN, C. 1990. Variscan oceans: Ages, origins and geodynamic implications inferred from geochemical and radiometric data. Tectonophysics $\mathbf{1 7 7}, 215-27$.

Pin, C. \& MARINI, F. 1993. Early Ordovician continental break-up in Variscan Europe: $\mathrm{Nd}-\mathrm{Sr}$ isotope and trace element evidence from bimodal igneous associations of the Southern Massif of Central France. Lithos 29. 177-96.

Roser, B. P. \& Korsch, R. J. 1986. Determination of tectonic setting of sandstone-mudstone suites using $\mathrm{SiO}_{2}$-content and $\mathrm{K}_{2} \mathrm{O} / \mathrm{Na}_{2} \mathrm{O}$-ratios. Journal of Geology 94, 635-51.

Roser, B. P. \& NATHAN, S. 1997. An evaluation of elemental mobility during metamorphism of a turbiditic sequence (Greenland Group, New Zealand). Geological Magazine 134, 219-34.

RöSler, H. J. \& BEUGE, P. 1983. Geochemistry of trace elements during regional metamorphism. In The Significance of Trace Elements in Solving Petrogenetic Problems and Controversies (ed. S. S. Augustithis), pp. 407-30. Athens: Theophrastus.

RöTZLER, K. 1995. Die PT-Entwicklung der Metamorphite des Mittel- und Westerzgebirges. Potsdam: Scientific Technical Report, GeoForschungsZentrum, STR95/14, 220pp.

Rötzler, K., Schumacher, R., Maresch, V. W. \& Willner, A. P. 1998. Characterization and geodynamic implications of contrasting metamorphic evolution in juxtaposed high-pressure units of the Western Erzgebirge (Saxony, Germany). European Journal of Mineralogy 10, 261-80.

SAWYER, E. W. 1986. The influence of source rock type, chemical weathering and sorting on the geochemistry of clastic sediments from the Quetico Metasedimentary Belt, Superior Province, Canada. Chemical Geology 55, 77-95.

SCHIEBER, J. 1990. Distribution of REE in the Eastern Belt Supergroup (Montana, USA). Implications for stratigraphic correlations and basin evolution. Chemical Geology 81, 83-98.

SChmädicke, E., Okrusch, M. \& Schmidt, W. 1992. Eclogite facies rocks in the Saxonian Erzgebirge, Germany: High-pressure metamorphism under contrasting $\mathrm{P}-\mathrm{T}$ conditions. Contributions to Mineralogy and Petrology 110, 226-41.

SChmäDICKe, E. \& Evans, B. W. 1997. Garnet-bearing ultramafic rocks from the Erzgebirge, and their relation to other settings in the Bohemian Massif. Contributions to Mineralogy and Petrology 127, 57-74.

SchwAB, F. L. 1975. Framework mineralogy and chemical 
composition of continental margin-type sandstone. Geology 3, 487-90.

SHAw, D. M. 1954. Trace elements in pelitic rocks. Part I: Variation during metamorphism. Geological Society of America Bulletin 67, 1151-66.

Tichomirowa, M., Belyatski, B. V., Berger, H. J. \& Koch, E. A. 1996. Geochronological investigations on grey gneisses from the Freiberg region (eastern Erzgebirge). Journal of Conference Abstracts 1, 620.

TAYLOR, S. R. \& MCLENNAN, S. M. 1985. The continental crust: Its composition and evolution. Oxford: Blackwell Scientific Publications, $312 \mathrm{pp}$.

Willner, A. P., Kröner, A. \& Teufel, S. 1996. Time of formation, peak of HP-metamorphism and cooling history of quartz-feldspar rocks from the Central Erzgebirge (Saxony/Germany). Journal of Conference Abstracts 1, 675.

Willner, A., Rötzler, K. \& Maresch, W. V. 1997. Pressure-temperature and fluid evolution of quartzofeldspathic metamorphic rocks with a relic high-pressure, granulite-facies history from the Central Erzgebirge. Journal of Petrology 38, 307-36.

WimmenAuER, W. 1984. Das prävariskische Kristallin im Schwarzwald. Fortschritte in der Mineralogie 6, 69-86.
WinChESTER, J. A. \& MAX, M. D. 1989. Tectonic setting discrimination in clastic sequences: An example from the late Proterozoic Erris Group, NW Ireland. Precambrian Research 45, 191-210.

Winchester, J. A., Floyd, P. A., Chocyk, M., Horbowy, K. \& KozdroJ, W. 1995. Geochemistry and tectonic environment of Ordovician meta-igneous rocks in the Rudawy Janowickie Complex, SW Poland. Journal of the Geological Society, London 152, 105-15.

WinCHESTER, J. A. \& MAX, M. D. 1996. Chemostratigraphic correlation, structure and sedimentary environments in the Dalradian of the NW Co. Mayo inlier, NW Ireland. Journal of the Geological Society, London 153, 779-801.

Wronkiewicz, D. J. \& Condie, K. C. 1987. Geochemistry of Archaean shales from the Witwatersrand Supergroup, South Africa: Source-area weathering and provenance. Geochimica et Cosmochimica Acta 51, 2401-16.

YounG, T. P. 1989. Eustatically controlled ooidal ironstone deposition: Facies relationships of the Ordovician openshelf ironstones of Western Europe. In Phanerozoic Ironstones (eds T. P. Young \& W. E. Taylor), pp. 51-63. Geological Society Special Publication 46. 